\title{
The Suzuki-Miyaura Cross-Coupling as a Versatile Tool for Peptide Diversification and Cyclization
}

\author{
Tom Willemse ${ }^{1,2}$, Wim Schepens ${ }^{3}$, Herman W. T. van Vlijmen ${ }^{3}$, Bert U. W. Maes ${ }^{2}$ \\ and Steven Ballet ${ }^{1, *}$ \\ 1 Research Group of Organic Chemistry, Departments of Bioengineering Sciences and Chemistry, \\ Vrije Universiteit Brussel, 1050 Brussels, Belgium; tomwille@vub.ac.be \\ 2 Organic Synthesis Division, University of Antwerp, 2020 Antwerp, Belgium; bert.maes@uantwerpen.be \\ 3 Discovery Sciences, Janssen Research and Development, 2340 Beerse, Belgium; wschepen@its.jnj.com (W.S.); \\ hvvlijme@its.jnj.com (H.W.T.V.V.) \\ * Correspondence: sballet@vub.ac.be; Tel.: +32-629-3292
}

Academic Editor: Ioannis D. Kostas

Received: 25 January 2017; Accepted: 21 February 2017; Published: 25 February 2017

\begin{abstract}
The (site-selective) derivatization of amino acids and peptides represents an attractive field with potential applications in the establishment of structure-activity relationships and labeling of bioactive compounds. In this respect, bioorthogonal cross-coupling reactions provide valuable means for ready access to peptide analogues with diversified structure and function. Due to the complex and chiral nature of peptides, mild reaction conditions are preferred; hence, a suitable cross-coupling reaction is required for the chemical modification of these challenging substrates. The Suzuki reaction, involving organoboron species, is appropriate given the stability and environmentally benign nature of these reactants and their amenability to be applied in (partial) aqueous reaction conditions, an expected requirement upon the derivatization of peptides. Concerning the halogenated reaction partner, residues bearing halogen moieties can either be introduced directly as halogenated amino acids during solid-phase peptide synthesis (SPPS) or genetically encoded into larger proteins. A reversed approach building in boron in the peptidic backbone is also possible. Furthermore, based on this complementarity, cyclic peptides can be prepared by halogenation, and borylation of two amino acid side chains present within the same peptidic substrate. Here, the Suzuki-Miyaura reaction is a tool to induce the desired cyclization. In this review, we discuss diverse amino acid and peptide-based applications explored by means of this extremely versatile cross-coupling reaction. With the advent of peptide-based drugs, versatile bioorthogonal conversions on these substrates have become highly valuable.
\end{abstract}

Keywords: Suzuki-Miyaura reaction; peptide diversification; peptide cyclization

\section{Introduction}

The Pd-catalyzed Suzuki-Miyaura reaction has found widespread use in the synthesis of carbon-carbon bonds [1,2]. The success of this cross-coupling reaction can be attributed to the generally mild reaction conditions required and the versatility of the boron species as organometallic partners [3-9]. Compared to related $\mathrm{C}-\mathrm{C}$ bond formations, the environmentally benign nature, high functional group tolerance, wide commercial availability of the reactants, and compatibility with aqueous conditions are advantageous [10-12]. As a result, various research groups have utilized and reviewed this reaction for the derivatization of complex molecules such as natural products [13-16] and nucleosides [17-23]. The mechanism of this reaction originally proposed by Miyaura and Suzuki has been revisited recently, which provides insights useful for rational reaction optimization [24-26]. Besides classical organoboronic acids, new boron-derived reagents 
have been developed with improved shelf life and controlled release of reactant and stability versus deborylation during cross-coupling $[4-9,27,28]$. In this review, we focus on the derivatization of amino acids up to protein substrates. In general, through bioorthogonal reactions, the site-selective derivatization of peptides and proteins is possible after the incorporation of non-proteinogenic amino acids and subsequent labeling of the (bioactive) substrate [29-33]. Additionally, this cross-coupling possesses a huge potential with regards to the improvement of peptide-based therapeutics and pharmacological probes. To achieve the envisaged site-selective modification, a single residue must undergo transformation in the presence of a significant amount of other side chains or functionalities In contrast, when multiple reactive sites are present, non-selective derivatization methods often yield less active conjugates that are difficult to separate [34]. To access the desired, pin-pointed modification, a wide array of halogenated and borylated residues (selected examples are shown in Figure 1) can for instance be incorporated in peptidic substrates, all of which allow diverse substitutions or cyclizations.
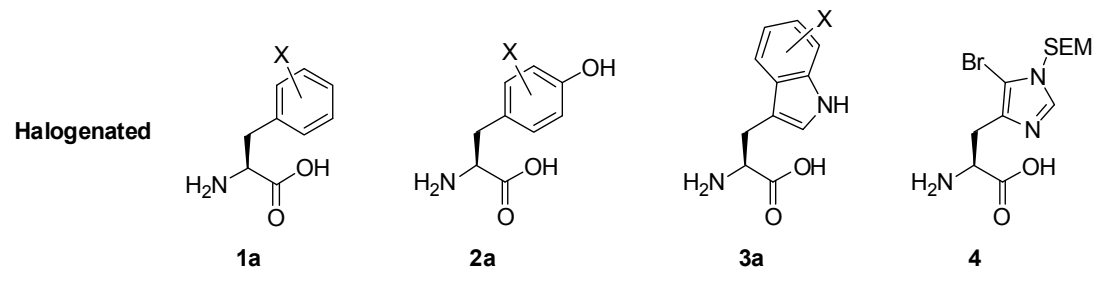

$\mathrm{X}=\mathrm{I}, \mathrm{Cl}, \mathrm{Br}$ or OTf

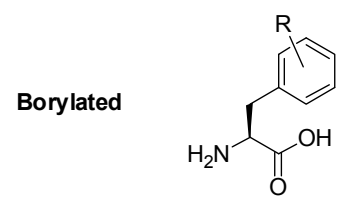

$1 b$

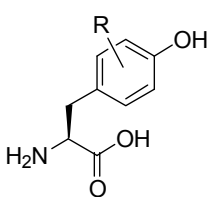

2b

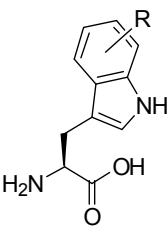

$3 \mathbf{b}$

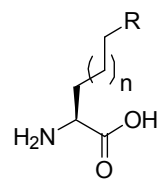

5

$\mathrm{R}=\mathrm{B}(\mathrm{OH})_{2}, \mathrm{BF}_{3} \mathrm{~K}, \mathrm{Bpin}, \mathrm{B}-\mathrm{MIDA}, 9-\mathrm{BBN}$

Figure 1. Representative examples of building blocks used in Suzuki-Miyaura-based derivatizations.

Halophenylalanines are generally commercially available, while (bio)synthetic methods have been developed for the preparation of halogenated tryptophans [35-38]. Boron groups are readily introduced in aromatic and aliphatic amino acids via borylation or hydroboration [39,40]. Insertion of these residues can be realized via solid-phase peptide synthesis (SPPS) methods utilizing the halogenated or borylated amino acid analogue. Next, peptide derivatization can be performed in solution-phase, after cleavage from the solid support. Alternatively, the direct Pd-catalyzed solid-phase derivatization has also been widely reported. The latter strategy offers the added value of a rapid purification by filtration, and hence removal of excess reactants, reagents, by- or side-products.

Due to the significant role that natural aromatic amino acids play in peptide-protein interactions [41], it can easily be perceived that additional interactions with the biological targets are within reach through usage of derivatized amino acids, prepared by the Suzuki-Miyaura reaction. The benefit of using non-natural amino acids has been well established [42-44], as the biological activity profile of the targeted peptide and its overall stability can be greatly enhanced through such modifications [45]. Ready access to a broad variety of unusual amino acids is therefore highly desirable for medicinal chemists, since they allow to perform structure-activity relationship studies. Hence, the Suzuki-Miyaura reaction serves as a powerful tool for peptide/medicinal chemists and it has certainly secured a place in their "toolbox" to improve peptide lead agents [45-47].

Furthermore, since both the halogen substituent and the boronate group are readily introduced, cyclization of the peptide can be achieved through Suzuki-Miyaura cross-coupling. Traditionally, cyclic peptides are often used as analogues of their linear counterparts to protect the peptide from 
a premature enzymatic degradation, to stabilize secondary motifs and lock the active conformation for an improved pharmacological profile [48]. Peptide macrocyclization has thus been developed to overcome the intrinsic drawbacks of peptide therapeutics [49-52]. In this regard, various strategies have emerged for the synthesis of constrained cyclic peptides with different structural motifs emerging at the site of macrocyclization. Commonly applied strategies include disulfide or lactam bridge formation [53], ring-closing metathesis (RCM) [54], azido-alkyne cycloaddition [55], and palladium-catalyzed reactions $[15,56,57]$. Of specific importance to the current review are the biaryl-bridges, which gained interest for the stabilization of $\alpha$-helices and $\beta$-sheets [58,59]. Interestingly, biaryl-linkages and moieties are also found in a variety of naturally occurring peptides and even synthetic drugs (e.g., Figure 2) [60,61].

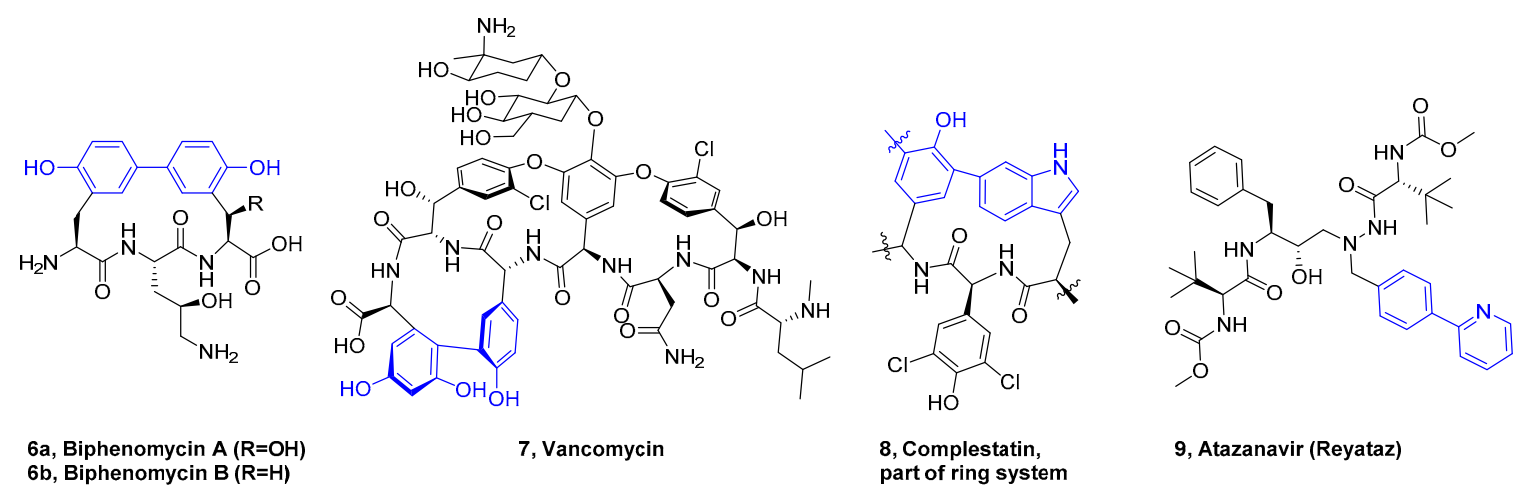

Figure 2. Naturally occurring peptides 6-8 and anti-retroviral drug Atazanavir 9 containing a biaryl moiety.

In light of the natural environment of peptide substrates, the importance of water as a (co-)solvent has been evaluated during Suzuki-Miyaura reactions applied on peptide substrates. The need for aqueous or mixed aqueous conditions is important for enabling the derivatization of unprotected amino acids or proteins, since such solvent systems ensure solubility of these complex products. The development of water soluble ligands and further improvement of catalysts for classical organic reactions [62] has encouraged peptide chemists to also explore mild conditions for amino acid/peptide derivatizations [63,64]. Such reaction conditions are preferred for amino acid(-based) substrates in order to avoid epimerization or other unwanted side reactions, while mild conditions are simply mandatory for protein substrates. Physiological conditions $\left(37^{\circ} \mathrm{C}\right.$, buffered aqueous solutions) are often considered to maintain the natural protein folding $[63,65]$.

In this review, the aim is to present, in a comprehensive manner, the major advances of the Suzuki-Miyaura cross-coupling in the field of peptide chemistry. Ever since the first reports in 1992, replacement of the typical organic reaction conditions, along with developments in chemical biology, has opened a plethora of potential applications. The usefulness of this cross-coupling has been shown on simple amino acids, synthetically prepared peptides, and large protein complexes. Herein, we focus on methodology development for both solution- and solid-phase derivatizations of increasingly complex substrates. Efforts towards peptidic natural product synthesis and peptide cyclization are discussed. In the final part, several biological applications in different therapeutic areas are briefly highlighted in which the Suzuki-Miyaura reaction represented a key reaction.

\section{Derivatization of Amino Acids and Peptides in Solution}

\subsection{Access to and Derivatization of (Pseudo)halogenated Aromatic Amino acid Substrates}

Halogenated residues can be introduced in peptide sequences via replacement of aromatic amino acids by their halogenated $(\mathrm{Cl}, \mathrm{Br}, \mathrm{I})$ or pseudohalogenated (OTf, OMs) analogues. In contrast to these aromatic amino acids bearing (pseudo)halogenated moieties, amino acid-based alkyl halides 
are not used directly as substrates in the Suzuki-Miyaura reaction. To date, their use is limited to the Negishi reaction of $\beta$-iodoalanine, $\beta$-iodohomoalanine, and iodobishomoalanine with various aryl iodides, to gain access to non-proteinogenic phenylalanine analogues [66-69]. For peptides that are prepared by chemical methods, SPPS easily enables the replacement of an aromatic amino acid with a non-natural (pseudo)halogenated analogue. Most of the (pseudo)halogenated phenylalanines are available from commercial sources. In contrast, the use of halotryptophans as substrates in Suzuki-Miyaura couplings was initially hampered by their limited commercial availability (NB: pseudohalogenated tryptophans and derivatization thereof have not been reported to date). Chemical synthesis of these building blocks often lack generality and require specific procedures for each regioisomer [70-73]. In view of this issue, a straightforward procedure for the enzymatic synthesis of halogenated tryptophans was described via use of tryptophan synthase on the corresponding readily available indole analogues $[37,74]$. This methodology affords Gram-scale quantities of enantiomerically pure chlorotryptophans, bromotryptophans, and more recently 7-iodotryptophan [75]. Site-specific halogenases of tryptophan have also been developed for the preparation of halotryptophans. [35-38,76,77] Complex protein substrates that contain halogenated residues and which are not accessible via chemical synthesis could also be specifically obtained by means of auxotrophic strains or reassignment of stop codons $[78,79]$. Pioneering work by the group of P. G. Schultz expanded the genetic code via a unique tRNA/aminoacyl-tRNA synthetase pair, resulting in a solid protocol to insert 4-iodophenylalanine [80] and 4-boronophenylalanine [81]. The introduction of 4-iodophenylalanine, for example, opened the gateway for protein modification via Pd-catalyzed reactions $[65,82,83]$.

While early cross-couplings on amino acid substrates include Sonogashira, Mizoroki-Heck, and Stille cross-couplings, the Suzuki-Miyaura reaction is most prominent in literature for the bioorthogonal derivatization of (pseudo)halogenated aromatic amino acid-containing substrates $[21,84,85]$. Initial work reported by Shieh et al. described the derivatization of protected L-tyrosine triflate 10 with different aryl boronic acids [86]. By combination of $\mathrm{Pd}\left(\mathrm{PPh}_{3}\right)_{4}$ and anhydrous $\mathrm{K}_{2} \mathrm{CO}_{3}$ in DMF (Figure $3 \mathrm{~A}$ ), racemization was observed (an ee as low as $66 \%$ was observed). However, by changing base to $\mathrm{Et}_{3} \mathrm{~N}$, racemization could be avoided, but the reaction time was significantly increased to two days. Improvement of the reaction conditions was realized by use of toluene and anhydrous $\mathrm{K}_{2} \mathrm{CO}_{3}$, which combined shorter reaction times with excellent yields and high optical purity. Derivatization of halogenated substrates 12 (Figure 3B) was first described by Burk and coworkers, and their pioneering work involved biphasic conditions (DME/aqueous base), and di- and tripeptide substrates [87]. During their optimalization, it was found that using $\mathrm{Pd}(\mathrm{OAc})_{2}$ in combination with $\mathrm{P}(o \text {-tol })_{3}$ yielded high conversion and no observable amounts of racemization. These conditions could be applied on protected 2-,3- and 4-bromophenylalanine 12, whereas the successful derivatization of several dipeptides and a tripeptide (containing methionine) demonstrated the versatility of this reaction. Kotha et al. further explored the derivatization on Boc-Phe(4-I)-OMe and small peptides (up to five residues: Boc-Ala-Leu-Phe(4-I)-D-Val-Val-OMe, not shown) [88]. In their work, $\mathrm{Pd}_{(}\left(\mathrm{PPh}_{3}\right)_{4}$ in a mixed THF/toluene solvent system, combined with an aqueous solution of inorganic base $\left(\mathrm{Na}_{2} \mathrm{CO}_{3}\right)$, afforded cross-coupled products starting from protected 4-iodophenylalanine with excellent yields and no reported racemization.

In following years, the substrate scope was further extended. Wang et al. showed that an asymmetric hydrogenation of 14, (with (S/S)/(R/R)[Et-DuPHOS-Rh]OTf), followed by Suzuki-Miyaura cross-couplings on protected 5-bromotrypthophan 15, afforded ready access to a series of novel tryptophan analogues $\mathbf{1 6}$ (Figure 4A) [89]. Intermediate 14 was prepared via Horner-Wadsworth-Emmons olefination of 5-bromo-3-formylindole and phosphonate $(\mathrm{MeO})_{2} \mathrm{P}(\mathrm{O}) \mathrm{CH}(\mathrm{NHCbz})-\mathrm{COOMe}$. The protected 5-bromotryptophan $\mathbf{1 5}$ was then submitted to similar conditions, as described by Burk [87], yielding bulky and hydrophobic 5-aryltryptophans (Figure 4A). In addition, Espuña published the first derivatization of an iodinated aspartame 17, bearing no protecting group at the $\mathrm{N}$-terminus and a side chain carboxylic acid (Figure 4B) [90]. 
A

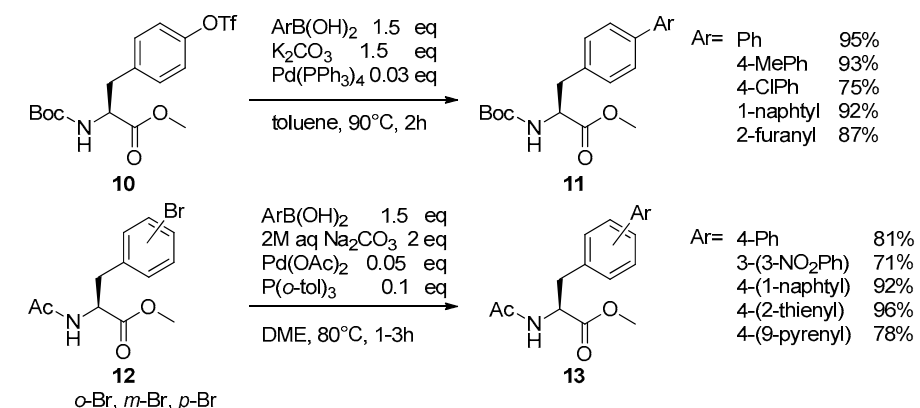

Figure 3. (A) First report of Suzuki-Miyaura reaction on 4-triflyloxyphenylalanine [86]. (B) Protected bromophenylalanines as substrates for cross-coupling.
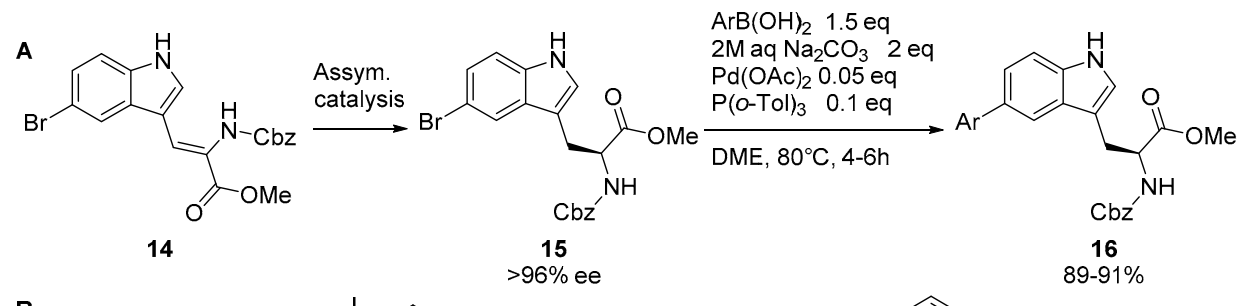

B

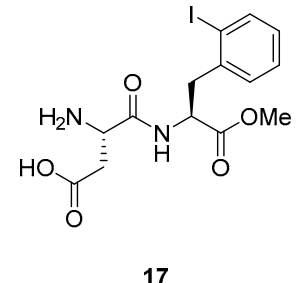

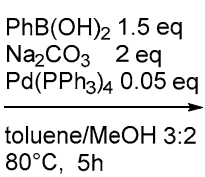
$80^{\circ} \mathrm{C}, 5 \mathrm{~h}$

17

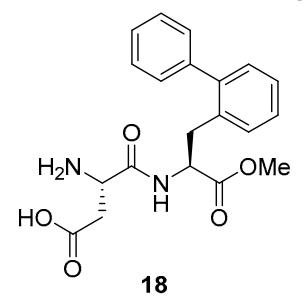

Figure 4. (A) Access to 5-aryltryptophans 16 via sequential asymmetric hydrogenation and Suzuki-Miyaura reaction. (B) Iodinated aspartame 17 transformed via cross-coupling.

Work published by Limbach et al. showed that protected 4-bromo- $\beta^{3}$-homophenylalanine 19 could be derivatized in mixed organic/aqueous (toluene $/ \mathrm{H}_{2} \mathrm{O}$ 8:1) conditions with a catalyst loading as low as $5 \mathrm{~mol} \%$ (Figure 5A) [91]. The substrate scope was further expanded by Knör and coworkers via introduction of protected 3-iodo-L-tyrosine as a substrate [92]. In their work, biphasic conditions (DME/aq. $\mathrm{Na}_{2} \mathrm{CO}_{3}$ ) were applied in combination with $\mathrm{Pd}(\mathrm{OAc})_{2}$ and $\mathrm{P}(o \text {-tol })_{3}$. Under these conditions, it was shown that protection of both the main chain termini and the phenol group was required. Cerezo reported the synthesis of 5-arylhistidines 22 under microwave conditions [93]. Ac-His-OMe was first treated with $\mathrm{N}$-bromosuccinimide (NBS) and subsequently protected with a 2-(trimethylsilyl)ethoxymethyl (SEM) group, to yield 21 . Due to the coordination potential of the imidazole ring of histidine, elevated reaction temperatures, combined with relatively high catalyst loading (up to $40 \mathrm{~mol} \%$ ) and $\mathrm{KF}$ as a base, were required (Figure 5B). Under these optimized conditions, a series of novel 5-substituted histidines 22 were prepared, but only in moderate yields and facilitated under microwave (MW) conditions. In an attempt to suppress the racemization of protected 3-bromo-4-methoxyphenylglycine (not shown), a substrate sensitive for racemization, Prieto and colleagues studied the Suzuki-Miyaura cross-coupling of protected phenylglycine with various aryl boronic acids [94]. It was found that, by means of mild bases, such as sodium succinate and potassium acetate, racemization could be avoided. Recently, Dumas et al. proposed the use of Pd-nanoparticles (ca. $5.6 \mathrm{~nm}$ diameter) as catalyst for Suzuki-Miyaura reactions in aqueous media for the derivatizations of Boc-protected halophenylalanine as the substrate [95]. In their work, the nanoparticles were stabilized on the surface of larger poly(D,L-lactide-co-glycolide)-block-poly(ethylene glycol) copolymer nanoparticles (PLGA-PEG 
NPs, ca. $158 \mathrm{~nm}$ diameter). These nano-assemblies were found to be excellently suited to catalyze the Suzuki-Miyaura coupling ( $1 \mathrm{~mol} \%$ ) of brominated and halogenated amino acids with arylboronic acids at $37^{\circ} \mathrm{C}$ for $18 \mathrm{~h}$ (98\% conversion) (Figure 5C). Remarkably, when potassium phenyltrifluoroborate or phenylboronic acid MIDA-ester ( $N$-methyliminodiacetic ester) were used, respectively $4 \%$ and no cross-coupled product was found. When cyclic triolborate derivatives (for example, potassium 4-methyl-1-phenyl-2,6,7-trioxa-1-borate-bicyclo-[2.2.2]-octane 24) were used, the reaction rate was improved in comparison with boronic acids. Moreover, the reaction could be carried out in slightly acidic media (phosphate buffer, $\mathrm{pH}=6.0$ ), which can be beneficial for substrates containing base-sensitive groups.

A

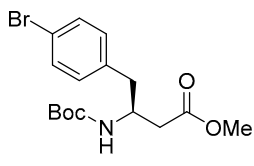

19

B

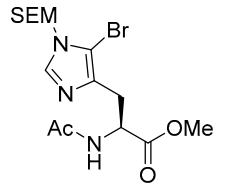

21

c

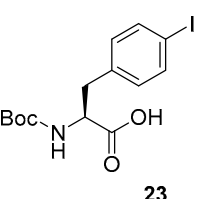

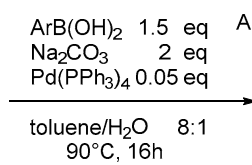

$90^{\circ} \mathrm{C}, 16 \mathrm{~h}$

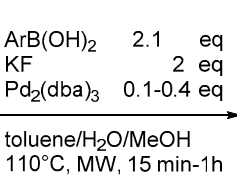
$110^{\circ} \mathrm{C}, \mathrm{MW}, 15 \mathrm{~min}-1 \mathrm{~h}$

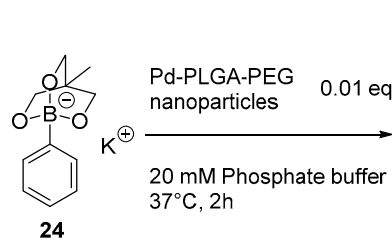

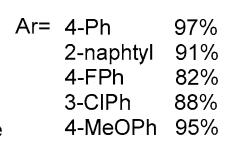

$\begin{array}{ll}4-\mathrm{MeOPh} & 85 \%\end{array}$

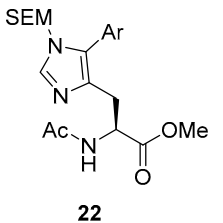

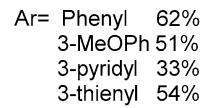

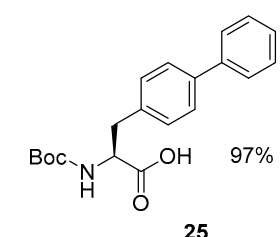

Figure 5. (A) Derivatization of $\beta^{3}$-homophenylalanine 19 in mixed aqueous conditions. (B) Protected 5-bromohistidine $\mathbf{2 1}$ as a substrate for arylation. (C) Cross-coupling with palladium nanoparticles yielding 25.

The derivatization of unprotected halotryptophans was first described by Deb Roy et al. under purely aqueous conditions, with the aid of the water-soluble trisulfonated triphenylphosphine (TPPTS) ligand, and $\mathrm{Na}_{2} \mathrm{PdCl}_{4}$ as a precatalytic system (Figure 6A), to generate tryptophan analogues 27 with fluorescent properties [64]. As expected, the obtained yields were highly dependent on the halogen atom present $(\mathrm{Br}>\mathrm{Cl})$, and derivatization on the 7-position afforded low yields. Further optimization indicated that a related ligand, bearing sulfonated $m$-xylene groups instead of phenyl (TXPTS), allowed for work at a lower temperature $\left(40^{\circ} \mathrm{C}\right)$ while still presenting excellent yields and significantly improved conversions when introducing a phenyl substituent on the 7-position. Alteration of the ligand to sulfonated 2-dicyclohexylphosphino-2'-6'-dimethoxybiphenyl (SSPhos) was necessary to maintain the applicability of the Suzuki-Miyaura reaction on 7-Cl-tryptophans, as beautifully illustrated by derivatization of the natural product chloropacidamycin in mixed aqueous conditions (water/acetonitrile (AcN) 5:1) [96]. The synthesis of 7-vinyltryptophan 29 with potassium vinyltrifluoroborate and $\mathrm{PdCl}_{2}(\mathrm{dppf})$, starting from 7-iodotryptophan 28 in mixed aqueous conditions (Figure 6B), broadened the scope of halotryptophan derivatization, along with the derivatization of unprotected bromotryptophan and bromotryptophan-containing dipeptides [97]. Recently, Frese et al. combined a biocatalytic and regioselective tryptophan halogenation and Suzuki-Miyaura cross-coupling in a multi-step one-pot reaction [98]. The benign halogenation is performed via immobilized tryptophan 5-, 6-, or 7-halogenases using $\mathrm{NaBr}$ as a halogen source, followed by biocatalyst removal and subsequent Suzuki-Miyaura reaction. The cross-couplings proceeded in high conversion with either SPhos in mixed aqueous conditions or SSPhos in purely aqueous conditions (Figure 6C). 
A
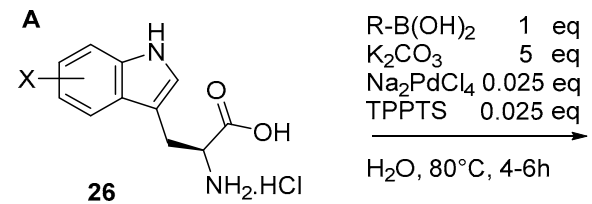

B

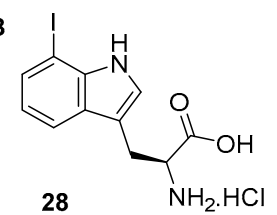

C

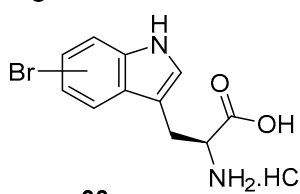

$\begin{array}{cc}\mathrm{BF}_{3} \mathrm{~K} & 2.5 \mathrm{eq} \\ \mathrm{K}_{2} \mathrm{CO}_{3} & 5 \mathrm{eq}\end{array}$ $\mathrm{PdCl}_{2}$ (dppf) $0.05 \mathrm{eq}$

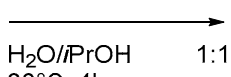

$80^{\circ} \mathrm{C}, 4 \mathrm{~h}$

$\mathrm{PhB}(\mathrm{OH})_{2} \quad 5$ eq

$\mathrm{K}_{3} \mathrm{PO}_{4} 25$ eq

$\mathrm{Na}_{2} \mathrm{PdCl}_{4} 0.05$ eq

SSPhos $0.15 \mathrm{eq}$

$\mathrm{H}_{2} \mathrm{O}, 100^{\circ} \mathrm{C}, 4 \mathrm{~h}$
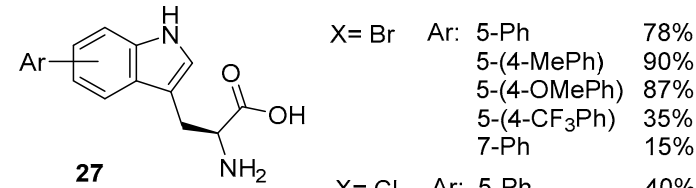

$\mathrm{X}=\mathrm{Cl} \quad$ Ar: $5-\mathrm{Ph} \quad 40 \%$

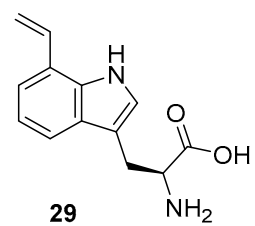

$80 \%$ conversion

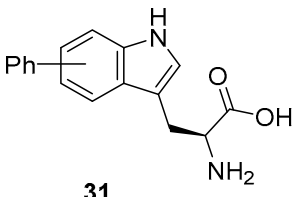

Multi-step One-pot procedure without intermediate isolation

After Boc-protection:

Boc-5-Ph-Trp-OH, 32\% Boc-6-Ph-Trp-OH, 75\% Boc-7-Ph-Trp-OH, 94\%

Figure 6. Derivatization of unprotected halotryptophans in aqueous conditions: (A) Arylation. (B) Vinylation. (C) Multistep one-pot biocatalytic halogenation presented 30, followed by Suzuki-Miyaura reaction.

As the Suzuki-Miyaura reaction is performed in basic conditions, the base labile 9-fluorenylmethyloxycarbonyl (Fmoc) protecting group is often not considered as part of a substrate. Nevertheless, Willemse reported Fmoc-iodophenylalanine as a substrate, and in their hands demonstrated that at $80{ }^{\circ} \mathrm{C}$ Fmoc-deprotection occurs when using $\mathrm{PdCl}_{2}$ (dppf) in mixed aqueous conditions ( $i \mathrm{PrOH} / \mathrm{H}_{2} \mathrm{O}$ 1:1) with $\mathrm{K}_{2} \mathrm{CO}_{3}$ (not shown) [97]. However, by lowering the reaction temperature to $40^{\circ} \mathrm{C}$, no deprotection occurred, but the reaction only reached a maximum conversion of $80 \%$ after $24 \mathrm{~h}$. Similarly, Maity et al. investigated the fluorescent properties of an amino acid containing a $4^{\prime}$-acetamido[1,1'-biphenyl] moiety [99]. The synthesis involved the successful Suzuki-Miyaura cross-coupling reaction of 4-acetamidophenyl-1-pinacolatoboron ester with Fmoc-4-bromophenylalanine step in $81 \%$ yield (not shown). The cross-coupling proceeded in the presence of $\mathrm{PdCl}_{2}$ and $\mathrm{Na}_{2} \mathrm{CO}_{3}$ in a mixture of THF and ethylene-glycol (10:1) at $66^{\circ} \mathrm{C}$. Recently, Qiao and coworkers reported the one-step synthesis of Fmoc-protected aryl substituted phenylalanines 33 (Figure 7) [100]. Formation of des-Fmoc product was minimized by using relatively mild conditions $\left(<80^{\circ} \mathrm{C}\right)$ and an organic solvent (THF or $t$-amylOH). Microscale high-throughput screening of diverse phosphine ligands indicated that $1,1^{\prime}$-bis(di-tert-butylphosphino)ferrocene (DTBPF) was optimal in combination with $\mathrm{Pd}(\mathrm{OAc})_{2}$ as $\mathrm{Pd}$-source and $\mathrm{K}_{3} \mathrm{PO}_{4}$ as a base. Under the optimized conditions, no ee erosion was observed. The developed methodology proved successful for generating Fmoc-Bip (biphenyl) derivatives with both aryl boronic acids containing e-withdrawing and e-donating groups. Preliminary experiments on a Fmoc-protected pentapeptide suggested that the reaction rate was significantly reduced and after $50 \mathrm{~h}$ only des-Fmoc products (3:1 starting bromide vs. product) were observed.

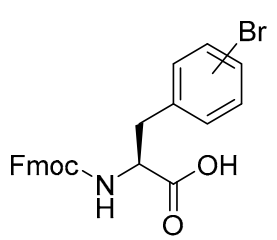

32

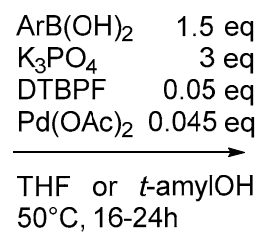

$50^{\circ} \mathrm{C}, 16-24 \mathrm{~h}$

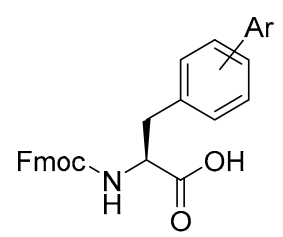

33

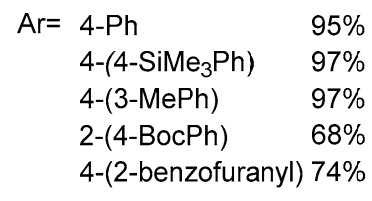

Figure 7. Synthesis of Fmoc-protected biphenylalanines 30. 


\subsection{Synthesis of Borylated Aromatic and Aliphatic Amino Acids and Subsequent Derivatization}

Most studies of the Suzuki-Miyaura reaction on biomolecules, such as amino acids and peptides, are performed on halogenated Trp, Phe, or peptide sequences containing these residues as a consequence of their good accessibility and straightforward introduction into sequences by means of SPPS. The incorporation of borylated amino acids into peptide sequences equally allows cross-coupling with aryl or alkyl halides. Coupling with alkyl halides in particular has the added advantage of an excellent commercial availability of structurally diverse halogenated reactants and their improved stability in comparison to alkylboronic acids. The latter compounds possess low stability and limited commercial availability, and easily undergo deborylation or $\beta$-hydride elimination after transmetallation [101]. The biological stability and role of boronic acids in therapeutic peptides has already been studied in detail since this functional group has been used in protease inhibitors, boron neutron-capture therapy, and cancer therapy (e.g., Bortezomib) [102].

Multiple borylated amino acids have been synthesized, both aliphatic and aromatic residues [39,40]. Introduction of boron can be achieved through different strategies which depend on the envisaged application. Synthetic methods standardly introduce a protected analogue of a boronic acid. The preparation of pinacolyl arylboronate esters in particular has been well described, either starting from Seebach's imidazolidinone $[103,104]$, via the Miyaura borylation of a (pseudo)halogenated phenylalanine [105-108], metal-halogen exchange [109], through direct Iridium-catalyzed borylation [110-112], or even Friedel-Crafts alkylation (selected examples are shown in Figure 8) [113]. Alternatively, direct synthesis of amino acids containing the MIDA-boronate ester group is also possible via Negishi coupling (not shown) [114].

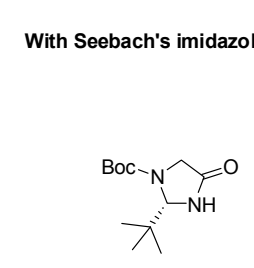

34

(Pseudo)halogenated Phe

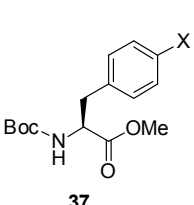

37

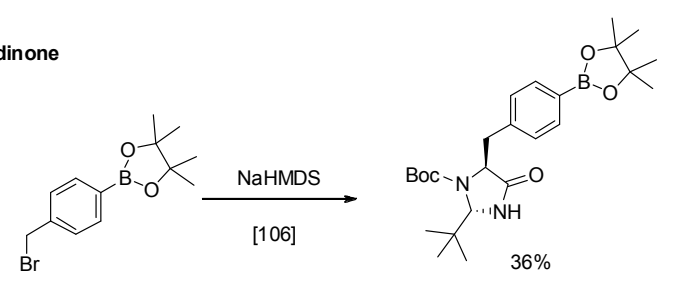

35

36
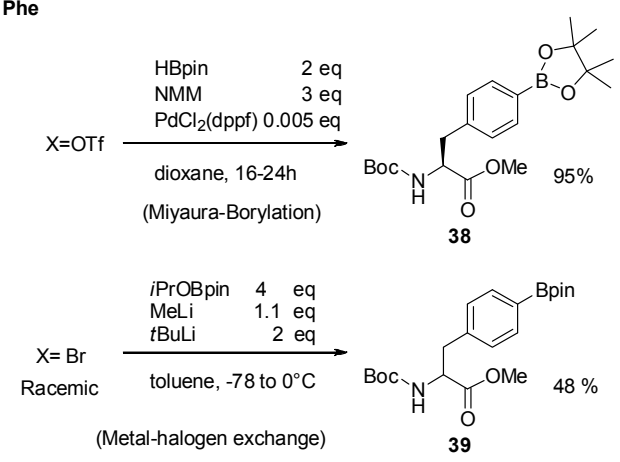

Ir-catalyzed C-H activation

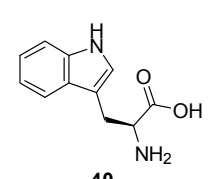

40

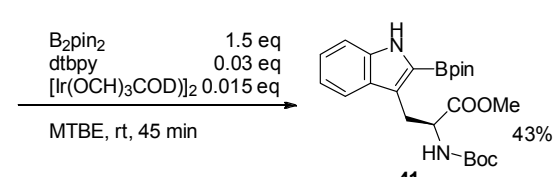

41

Friedel-Crafts acylation

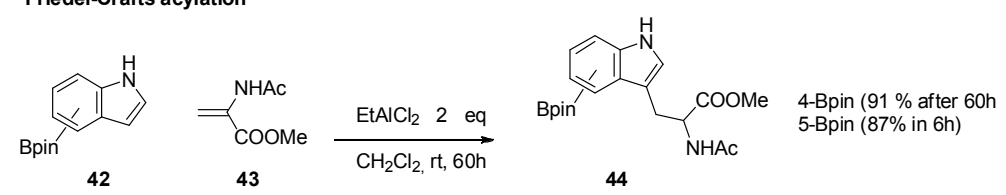

Figure 8. Representative examples of methods to prepare pinacolyl arylboronate esters. 
The cross-coupling of 4-pinacolylborono-L-phenylalanine [L-Phe(4-Bpin)] 45 with aryl iodides was first reported by Satoh et al. When aryl bromides and triflates in combination with the pre-catalyst $\mathrm{PdCl}_{2}$ (dppf) were used, moderate yields resulted (Figure 9A) [103]. In the same year, an extension of this study was reported by Firooznia, describing the derivatization of racemic Boc-Phe(4-Bpin)-OEt with aryl chlorides, conversions which required the alkylphosphine-based precatalyst $\mathrm{PdCl}_{2}\left(\mathrm{PCy}_{3}\right)_{2}$ [104]. Their methodology was however limited to electron-donating aryl chlorides. Enantiomerically pure Boc-L-Phe(4-Bpin)-OMe was also derivatized by the same group through application of the previously published conditions of Satoh et al. [103], which used $\mathrm{PdCl}_{2}$ (dppf) in DME. It was also shown that racemic, unprotected 4-boronophenylalanine (4-BPA) could be derivatized under microwave conditions $\left(150^{\circ} \mathrm{C}, 5-10 \mathrm{~min}\right)$ [115]. Optimal conversion was achieved when $\mathrm{PdCl}_{2}\left(\mathrm{PPh}_{3}\right)_{2}$ was used in combination with $\mathrm{Na}_{2} \mathrm{CO}_{3}$ in water/acetonitrile (1:1) as a solvent. Čapek et al. investigated the cross-coupling of unprotected 4-boronophenylalanine with halogenated nucleosides [116,117]. Surprisingly, use of protected nucleosides in combination with $\mathrm{Pd}(\mathrm{OAc})_{2}$ and JohnPhos in dioxane proved to be ineffective. However, when the water-soluble TPPTS ligand was employed with unprotected 8-bromoadenine nucleosides and 4-boronophenylalanine, efficient cross-couplings followed. These reactions were facilitated by microwave irradiation at $150{ }^{\circ} \mathrm{C}$ for $5 \mathrm{~min}$, yielding the desired compounds in excellent optical purity, as determined by FDAA analysis [116]. Following these results, Čapek and coworkers also successfully coupled 6- or 8-halogenated purine nucleosides with 4-BPA in the presence of TPPTS and $\mathrm{Pd}(\mathrm{OAc})_{2}$ [117]. In addition to pinacol esters, the MIDA boronate group was also introduced on aromatic amino acids such as 49 by Colgin et al. [114]. Starting from compounds 47 and 48 , a Negishi coupling and subsequent Suzuki-Miyaura reaction yielded $\mathbf{5 0}$ in mixed aqueous conditions (dioxane $/ \mathrm{H}_{2} \mathrm{O}$ 10:1) with $\mathrm{Pd}(\mathrm{OAc})_{2}$ as the precatalyst and SPhos as ligand (Figure 9B). Very recently, Bartocinni showed that racemic (7-pinacolborono)tryptophan $\mathbf{5 1}$ can be transformed to biaryl products $\mathbf{5 2}$ via Suzuki-Miyaura reaction in mixed aqueous conditions (Figure 9C) [118]. Similarly, access to (7-pinacolborono)tryptophan via selective Ir-catalysis allowed Loach to prepare arylated tryptophan derivatives [119]. Meyer et al. reported the selective borylation of phenylalanine (in the presence of a directing group, for example $\mathrm{Cl}$ on the 3-position) and heteroaromatic amino acids, such as 2-thienylalanine, 3-pyridinylalanine, and tryptophan [111]. To show the applicability of their methodology, protected borylated thienylalanine 54 was converted to 55 (Figure 9D). When comparing the optimized reaction conditions found for the derivatization of arylboronate esters with conditions commonly applied for the Suzuki-Miyaura reaction of halogenated amino acids and peptides, one can conclude that in the former case higher reaction temperatures and/or prolonged reaction times are often required. In addition, the limited stability of pinacolyl boronate esters towards conditions commonly applied during solid-phase peptide synthesis requires careful design of the peptide assembly [120]. Although the use of other protected alkylboronic acid analogues may circumvent this problem, as exemplified via MIDA-boronates [114], the pinacol ester functionality is used in most cases.

In contrast to the absence of Suzuki-Miyaura reactions involving amino acid-based alkyl halides, the synthesis and derivatization of borylated aliphatic amino acids have been described extensively. These have been prepared via hydroboration of protected allylglycine [121-125], quenching of a lithiated serine analogue with triisopropylborate [126], a Cu-catalyzed cross-coupling of gem-diborylalkanes with primary alkyl halides [127], and very recently by Pd-catalyzed C( $\left.\mathrm{sp}^{3}\right)-\mathrm{H}$ bond activation (selected examples are shown in Figure 10, left side) [128]. 

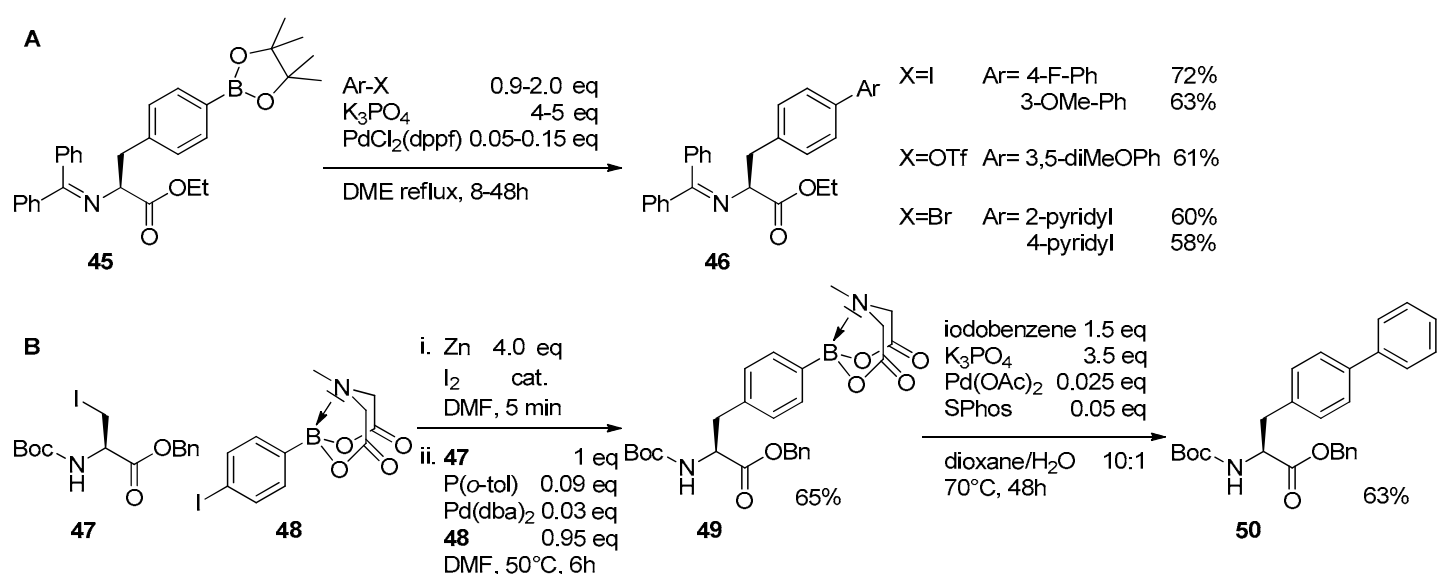

C
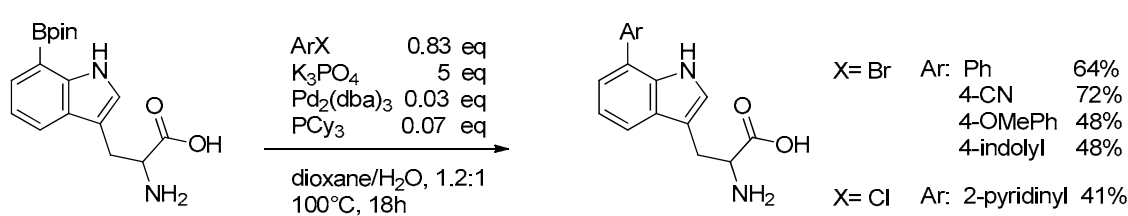

51

52

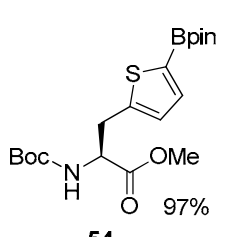

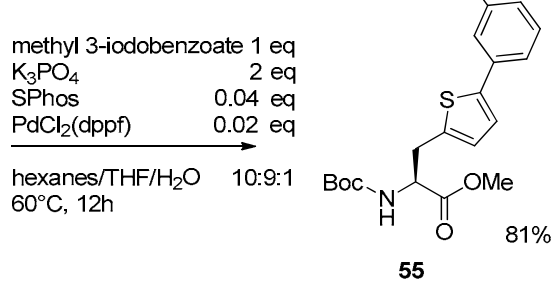

55

Figure 9. (A) Derivatization of $N$-benzophenone protected pinacolboronophenylalanine 45 with aryl halides. (B) Biphenylalanine 50 synthesis from the corresponding MIDA-boronate 49. (C) Preparation of racemic 7-aryltryptophan $\mathbf{5 2}$ by Suzuki-Miyaura reaction of the unprotected pinacolborono-D/L-tryptophan 51. (D) Protected thienylalanine 53 transformed to biaryl 55 via subsequent Ir-catalyzed borylation and Suzuki-Miyaura cross-coupling.

Campbell prepared bishomophenylalanine derivatives 58 by hydroboration of protected allylated oxazolidine 56 with 9-borabicyclo[3,3,1]nonane (9-BBN), followed by Suzuki-Miyaura reaction with aryl iodides and phenyl bromide in good yields (Figure 10A) [121]. The homologated phenylalanine analogues were obtained in mediocre yields (30\%-50\%) after oxidation with Jones' reagent $\left(\mathrm{CrO}_{3} / \mathrm{H}_{2} \mathrm{SO}_{4}\right)$ (not shown). Comparable work was also published by Sabat, which expanded the scope of the reaction to aryl triflates and heteroaryl bromides as substrates, giving way to oxazolidines like 58 in decent yields [122]. The oxidation protocol was further optimized to obtain the $\alpha$-amino acid analogues in yields up to $82 \%$ with excellent optical purity. Collier et al. further improved the procedure by performing the hydroboration-Suzuki protocol directly on protected allylglycine 59, yielding bishomophenylalanine derivatives $\mathbf{6 1}$ in two steps (Figure 10B) [123]. Extension to higher phenylalanine homologues was achieved by Rodríguez and coworkers [124]. In their work, but-3-enylglycine was prepared via Negishi coupling and after hydroboration, access to higher homologues was realized via Suzuki-Miyaura cross-couplings (not shown). Alternatively, a borylated serine analogue 63 was prepared by Harvey et al. by quenching an organolithium species (derived from 62) with triisopropylborate. This building block was transformed to non-proteinogenic phenylalanine analogues 64 by Suzuki-Miyaura reaction in the presence of $\mathrm{Ag}_{2} \mathrm{O}$ (Figure 10C). The corresponding amino acid was obtained after consecutive 2-(trimethylsilyl)ethoxymethyl (SEM) deprotection and a two-step oxidation with Dess-Martin periodinane and Pinnick oxidation (not shown). 

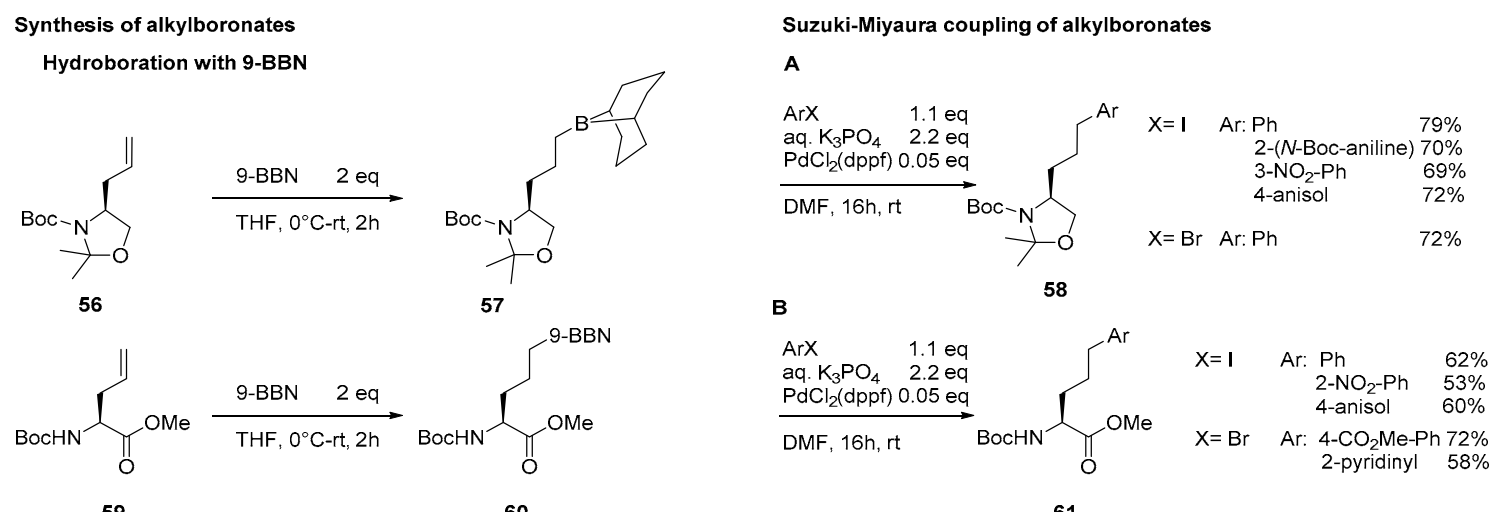

59

60

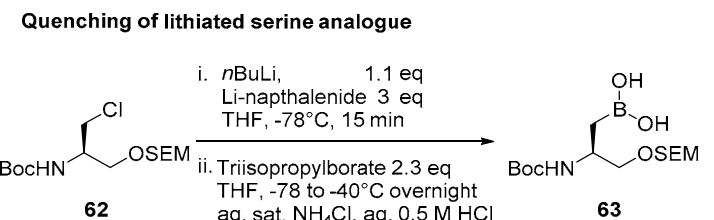

C

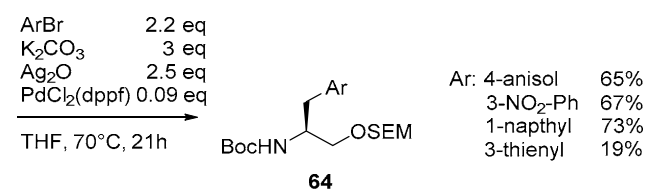

Cu-catalyzed coupling with gem-diborylalkanes

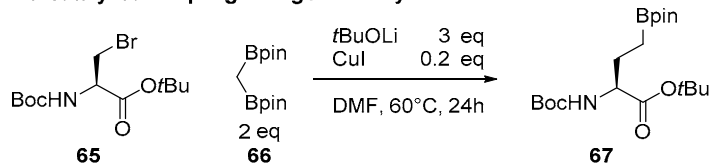

Pd-catalyzed C-H bond activation

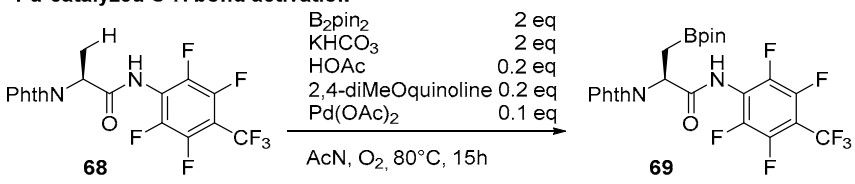

Figure 10. (Left) Representative examples of the preparation of amino acid alkylboronates. (Right) Synthesis of phenylalanine and analogues thereof prepared (A) via hydroboration/Suzuki-Miyaura protocol on protected allylated oxazolidine 56 (B) directly from protected allylglycine 59 or (C) from borylated serine analogue 63 .

\subsection{Coupling of Amino Acids: Synthesis of Biaryl-Bridged Dipeptides}

Yoburn investigated the synthesis of protected dityrosine substrate 70 (Figure 11) [129]. Initially, homocoupling of Ac-Tyr(3-I, 4-OBn)-OMe was performed in a one-pot borylation-Suzuki-Miyaura protocol with $\mathrm{PdCl}_{2}$ (dppf) and $\mathrm{B}_{2} \mathrm{pin}_{2}$. Here, $\mathrm{K}_{2} \mathrm{CO}_{3}$ was essential as a base in order to obtain efficient cross-coupling, since use of KOAc only led to borylation of the iodotyrosine educt. Reaction rates and conversions were however significantly lower when the substrate's complexity was increased, for example, to tripeptides. Next, isolation of the borylated peptide intermediate was envisaged and coupling proceeded smoothly when KOAc was used as a base. As such, Suzuki-Miyaura cross-coupling between peptide substrates bearing iodo- and boronotyrosine residues proceeded efficiently, and a viable strategy for homodimerizations (up to heptapeptides) was realized. These findings were simultaneously reported by Hutton et al. [130]. Similarly, Kotha synthesized dimers of protected phenylalanine $\mathbf{7 1}$ with racemic 4-boronophenylalanine and 4-iodophenylalanine (Figure 11), along with several unnatural bis-armed amino acids containing a variable number (one to five) of benzene rings [131]. In addition to their investigations on the racemization of phenylglycine under Suzuki-Miyaura conditions [94], Prieto further elaborated on the cross-coupling between 4-hydroxyphenylglycine and tyrosine or tryptophan derived building blocks [132]. Using standard reaction conditions, up to $32 \%$ of undesired diastereoisomer was found. Racemization could be suppressed (with up to $99 \%$ ee) via usage of the Buchwald ligand SPhos [9], eventually yielding biaryl 
building block 72 (Figure 11). Synthesis of these biaryl-bridged building blocks $\mathbf{7 1 - 7 2}$ represents a basis to obtain cyclic peptides when intramolecular couplings are performed (vide infra).
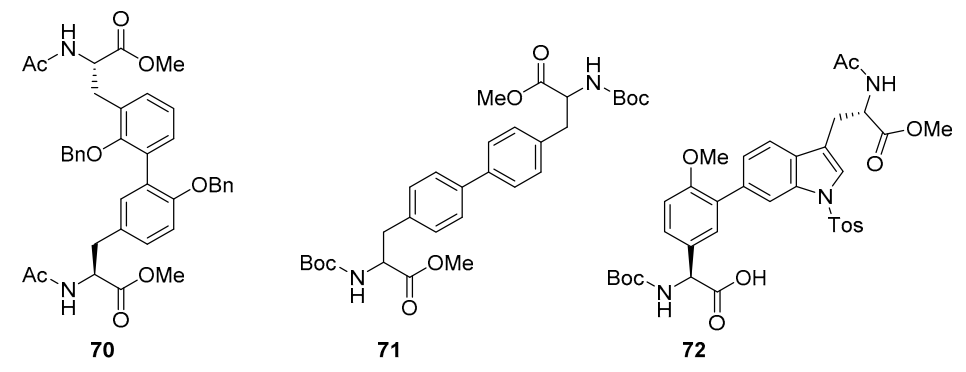

Figure 11. Amino acid homo- and heterodimers $45-47$ by intermolecular Suzuki-Miyaura cross-coupling.

\subsection{Suzuki-Miyaura Reaction on Peptidic Substrates}

Transposition of the Suzuki-Miyaura reaction from amino acid to larger, more complex peptides substrates required adapted methodologies. While solubility of protected amino acid substrates in organic solvents is not an issue, peptide substrates, and by extension proteins, are preferentially treated in aqueous conditions. Circumvention of the traditional solvents (e.g., toluene, DMF, dimethoxyethane) and lower reaction temperatures complicated the envisaged transformations. Moreover, application of the reaction with water as (co-)solvent demands a catalytic system that achieves high conversions in this environment, whilst avoiding side product formation. One needed to move away from the use of $\mathrm{Pd}\left(\mathrm{PPh}_{3}\right)_{4}, \mathrm{Pd}_{2}(\mathrm{dba})_{3}$ or $\mathrm{Pd}(\mathrm{OAc})_{2}$, combined with classical (phosphine) ligands such as the ones used in sections above (Figure 12, compounds 73-76), and out-of-the-box catalytic systems were required. One solution was found in designing more hydrophilic analogues of traditional ligands [11,62]. For example, 3,3',3'-phosphanetriyltris(benzene sulfonic acid) trisodium salt (TPPTS 77a, Figure 12) [18,64], its xylene analogue TXPTS 77b [64,133], sodium 2-dicyclohexylphosphino-2',6'-dimethoxybiphenyl-3'-sulfonate (SSPhos 78) [10,96], and water-soluble NHC-ligands ( $N$-heterocyclic carbene), such as 79 [134-137], have been proposed for Pd-catalysis in aqueous media (Figure 12). Suzuki-Miyaura reactions encompassing other water soluble ligands $[11,12,138]$, or additives such as polyethyleneglycol and surfactants were also applied $[11,34,139]$ Notably for Suzuki-Miyaura reaction in aqueous conditions, ligands containing the guanidine functionality, such as 2-aminopyrimidine-4,6-diol disodium salt (ADHP 80a) [63,140], its dimethylated analogue ( $N, N$-diMeADHP 80b) [34], and (methyl)guanidines 81 and 82 [34,141,142], have been reported.

The development of peptide diversification through Suzuki-Miyaura reactions in a purely aqueous environment was first reported by Vilaró et al. [143]. By combination of $\operatorname{Pd}(\mathrm{OAc})_{2}$ and the water-soluble sulfonated triphenylphosphine (TPPTS) ligand, couplings were realized in aqueous media on unprotected peptides 83 in very mild conditions (Figure 13A). Nearly quantitative yields were reported starting from the iodinated Leu-enkephalin analogue 83 , bearing neither main chain nor side chain protection. These transformations were realized upon application of potassium aryltrifluoroborates as reactants $[7,9]$. As expected, it was found that not only the length of the peptide chain, but also its respective amino acid composition were critical. For example, conversions in the presence of a histidine residue were greatly reduced. This can easily be rationalized by a potential complexation of unprotected side chains - but also the main chain termini- with the palladium catalyst, hence interfering with the envisaged derivatizations. During their exploration for phosphine-free catalyst systems, Chalker et al. observed that an aqueous solution of the sodium salt of ADHP 80a and $\mathrm{Pd}(\mathrm{OAc})_{2}$ could be used for cross-couplings of partially unprotected substrates like 85 in purely aqueous conditions (Figure 13B) [63]. In addition, mono- and bis-arylations were realized when, respectively, 3-iodotyrosine or 3,5-diiodotyrosine was introduced in the unprotected peptide sequence. 
Despite limited catalyst loadings (1-4 mol \%), high conversions were obtained for halogenated phenylalanines, tyrosines, and $p$-iodobenzyl cysteine (Pic, such as in 85). In contrast, in case of reactions on chlorophenylalanine- or substrates bearing Cys (unprotected in the side chain), these derivatization reactions were unsuccessful, presumably, due to the fact that the palladium catalyst is not electron-rich enough. Extension of their work showed that both the dimethyl analogue of ADHP (i.e., $\mathrm{Me}_{2} \mathrm{ADHP} \mathbf{8 0 b}$ ) and methylated guanidine $\mathbf{8 1}$ or $\mathbf{8 2}$ outperformed the ADHP catalyst system when a complex PEG-bound phenylboronic acid was utilized [34]. The latter consisted of monomethoxy-PEG (MW 2 k or $20 \mathrm{kDa}$ ) linked to 4-propylcarbamoylphenylboronic acid.

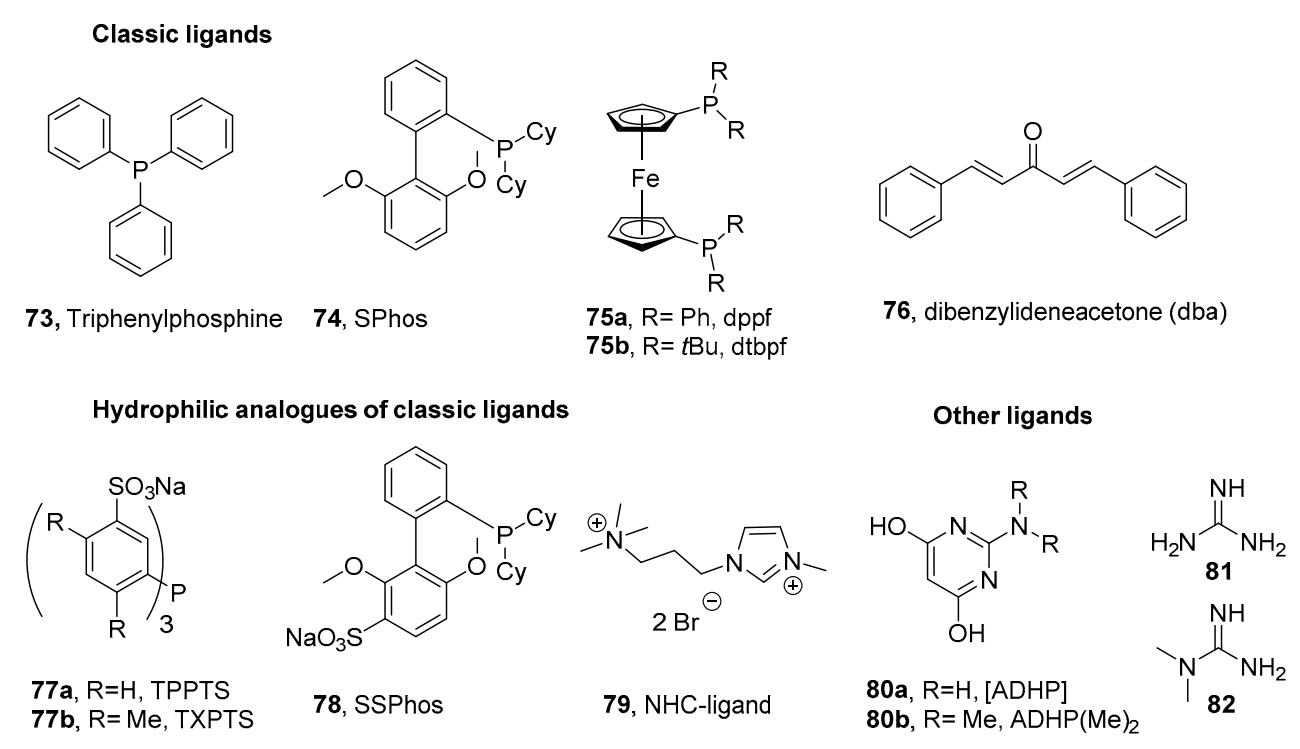

Figure 12. Ligands used Suzuki-Miyaura cross-coupling reactions on peptides. Classical ligands (73-76) that have commonly been used in the early developments on protected peptide substrates. Hydrophilic analogues (77-79) and non-classical ligands (80-82) used in aqueous media.

In order to unravel side/main chain functionality that hampers the application of Suzuki-Miyaura conversions on peptides, Willemse et al. performed a systematic screening of unprotected peptide main and side chain functionalities with various aqueous soluble ligands on dipeptide substrates of type 87 (Figure 13C) [97]. It was shown that, in purely aqueous conditions, a precatalyst solution of $\mathrm{ADHP}$ and $\mathrm{Pd}(\mathrm{OAc})_{2}$ led to efficient derivatizations of dipeptides containing 4-bromophenylalanine. Presence of histidine, bearing an imidazole moiety, and asparagine, bearing a primary amide, were revealed to be troublesome during the targeted cross-couplings. Alteration of the catalytic system to the ferrocene-containing catalyst $\mathrm{PdCl}_{2}(\mathrm{dppf})$ resulted in improved conversions in these cases. However, in order to achieve solubility of the catalyst and efficient cross-couplings, a water/iPrOH mixture was required. For the investigated histidine-containing peptides, maximum conversions of approximately $50 \%$ were reached, despite efforts to pre-saturate the imidazole moiety by the addition of sacrificial Lewis acids (e.g., $\mathrm{MgCl}_{2}$ ) prior to the cross-coupling, as was previously successfully reported for ring-closing metatheses (RCM) and Heck reactions [82,144,145]. Derivatizations on a large peptide $(89,34$ amino acid residues) in aqueous conditions were performed by Ojida et al. [146] (Figure 13D). Synthetic analogues of the WW domain (6-39) of PinI protein were prepared via SPPS assembly of a peptide containing an iodophenylalanine residue and subsequent Suzuki-Miyaura reactions. Experiments indicated that the addition of glycerol $(10 \% \mathrm{v} / \mathrm{v})$, known to stabilize proteins, to a Tris- $\mathrm{HCl}$ buffer ( $\mathrm{pH} 8$ ) was mandatory to reach high yields. Remarkably, the reaction temperature could be limited to $40{ }^{\circ} \mathrm{C}$ when using 1 equivalent of $\mathrm{Na}_{2} \mathrm{PdCl}_{4}$. 
A

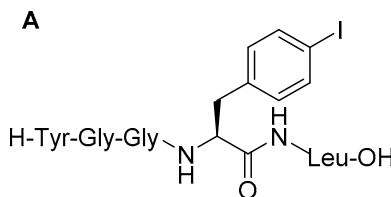

83<smiles>CC(C)(C)OC(=O)N[C@@H](CCC(=O)NC(CSCc1ccc(I)cc1)C(=O)NCC(=O)O)C(=O)O</smiles>

85

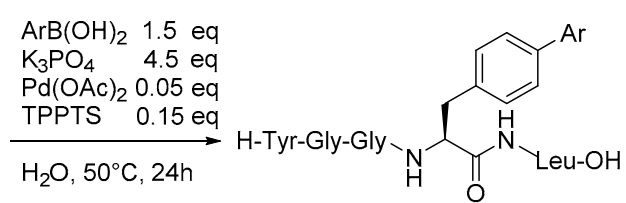

84

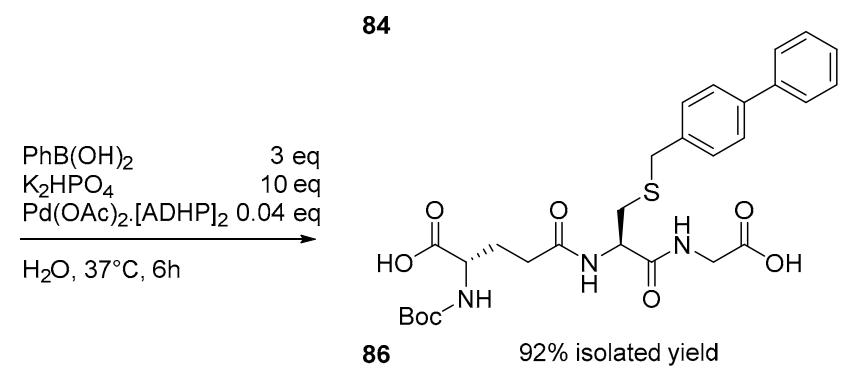

D

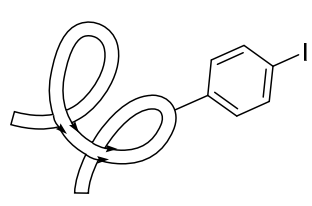

89

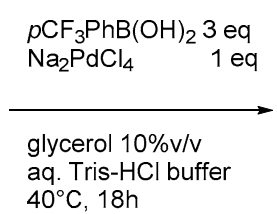
$40^{\circ} \mathrm{C}, 18 \mathrm{~h}$

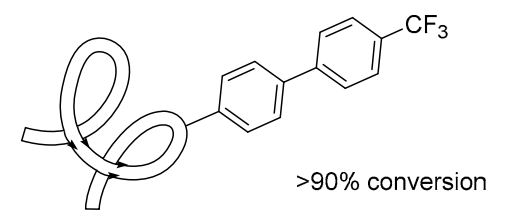

90

WW-domain iF34

Figure 13. Suzuki-Miyaura reactions on peptides (A) Unprotected pentapeptide 83 as a substrate. (B) Internal $p$-iodobenzylcysteine residue transformed to biaryl tripeptide 86. (C) Use of unprotected dipeptides 87. (D) Derivatization of 34-mer 90.

\section{Solid-Phase Derivatizations of Peptide Substrates}

Alternatively to Pd-catalyzed cross-couplings in solution, the derivatization of solid supported substrates offers advantages such as convenient washing steps and easy removal of any excess or unreacted reagents and reactants through filtrations $[147,148]$. For these cross-couplings on resin, the solvent is of high importance, as it is related to the swelling properties of the solid support. Typically, polystyrene-based resins are used for solid-phase peptide synthesis (SPPS) in organic media (e.g., DMF, $\mathrm{CH}_{2} \mathrm{Cl}_{2}$ ), whereas very limited swelling is observed in aqueous conditions or upon use of polar solvents. Alternatively, PS-PEG copolymer resins have been developed to improve swelling in mixed aqueous or polar conditions [149-151]. Of relevance to the current review, the preparation of a solid supported phenylalanine scaffold was first performed by Colombo [152]. Herein, it was shown that the Suzuki-Miyaura reaction of 4-iodophenylalanine anchored on Rink Amide resin was possible by means of biphasic conditions $(\mathrm{EtOH} /$ toluene $7: 3), \mathrm{Pd}\left(\mathrm{PPh}_{3}\right)_{4}$ precatalyst, and an aqueous solution of $\mathrm{Na}_{2} \mathrm{CO}_{3}$, albeit full conversion was not reached in these reactions. In their work, Wang resin was the first to be evaluated as the solid support; however, under the applied conditions, significant loss of product because of benzyl ester hydrolysis (i.e., linkage between amino acid and support), and low purity was observed. Performing the reaction on Rink Amide resin afforded desirable transformations. Limbach et al. reported Suzuki-Miyaura reactions on a Rink 
Amide resin linked pentapeptide containing a brominated $\beta^{3}$-homophenylalanine [91]. In their hands, $\mathrm{Pd}\left(\mathrm{PPh}_{3}\right)_{4}$ and $\mathrm{Na}_{2} \mathrm{CO}_{3}$ in a mixture of $\mathrm{EtOH} /$ toluene $/ \mathrm{H}_{2} \mathrm{O}$ solvent system resulted in high conversion. The "on support" derivatization was further elaborated by Nielsen et al. on hydroxymethylbenzoic acid-polyethylene glycol (HMBA-PEG) resin (Figure 14A) [153]. Peptide substrates anchored on this base-labile resin and containing either a 3- or 4-iodophenylalanine residue were derivatized to yield Compound 92 after coupling with a variety of arylboronic acids, $\mathrm{K}_{3} \mathrm{PO}_{4}$ and $\mathrm{PdCl}_{2}$ (dppf) in a biphasic $\left(t \mathrm{BuOH} /\right.$ toluene $\left./ \mathrm{H}_{2} \mathrm{O}\right)$ medium.

Similarly, Le Quement and co-workers reported the solid-phase derivatization of thienylalanine containing peptides 93 (Figure 14B) on HMBA-PEG 800 resin [154]. By solid-phase peptide synthesis, the 3-thienylalanine residue was introduced and subjected to Pictet-Spengler cyclization and bromination, to obtain 94 on support. From this compound, a set of cross-coupled products 95 could be obtained in good yields. Under analogous conditions, a derivatization strategy was employed to access biaryl pentapeptides with antagonistic effect on inhibitors of apoptotic proteins [155]. Additionally, a library of antimicrobial peptides was prepared by Haug et al. via the Suzuki-Miyaura reaction on tripeptides containing 4-iodophenylalanine [156]. Here, a Rink Amide linker on NovaGel resin (i.e., a PS-PEG resin) was employed as the solid support for the preparation of the Boc-Arg(Pbf)-Phe(4-I)-Arg(Pbf)-Rink amide educt. Successful cross-couplings with different bulky arylboronic acids were realized with $\mathrm{Pd}(\mathrm{OAc})_{2}$ and $\mathrm{P}(o \text {-tolyl })_{3}$ as the catalyst system in mixed $\mathrm{DME} / \mathrm{H}_{2} \mathrm{O}$ (not shown).

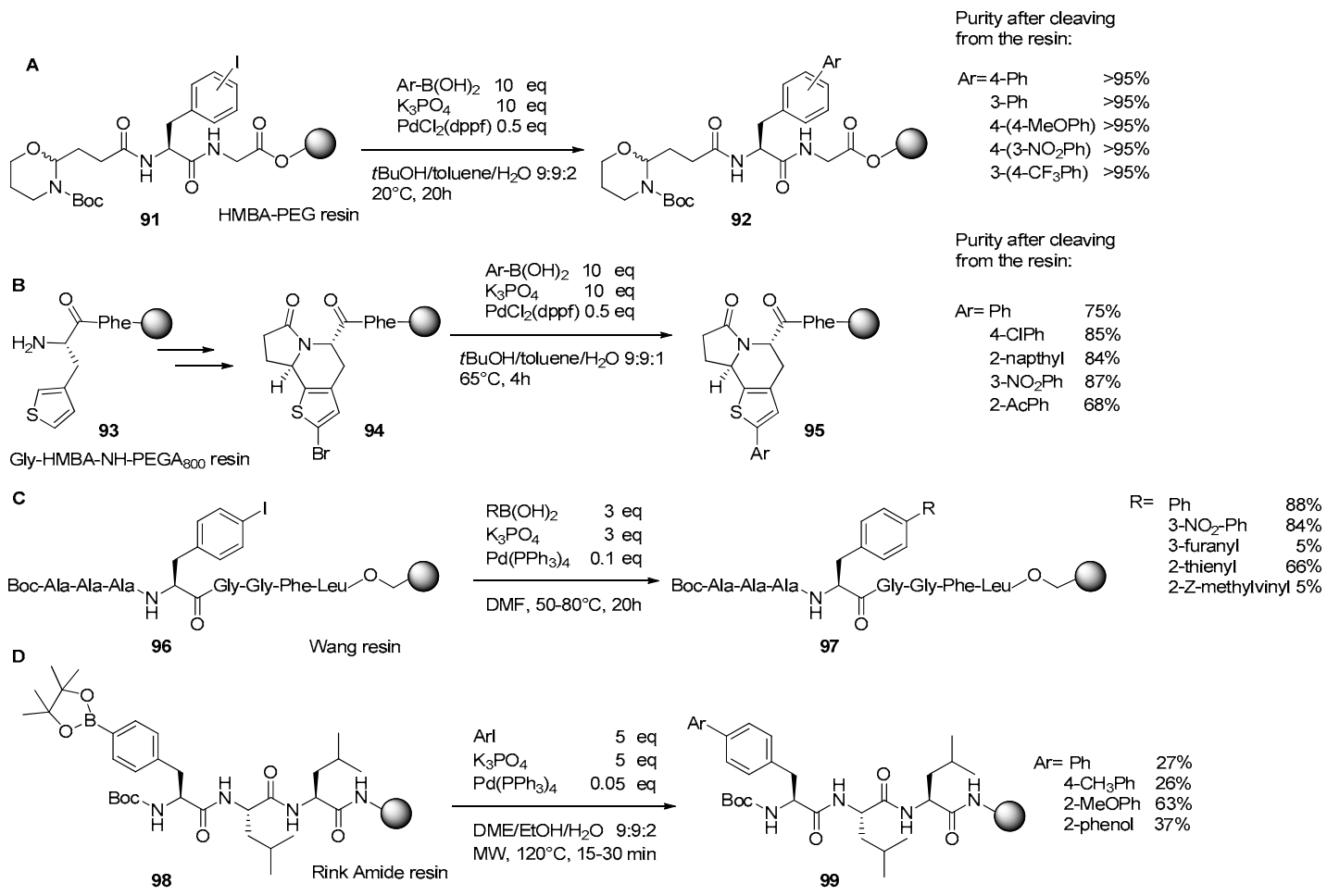

Figure 14. Solid-Phase derivatization via Suzuki-Miyaura cross-coupling (A) with iodophenylalanine containing 91, (B) with bromothienylalanine containing 94, (C) with 4-iodophenylalanine containing octapeptide 96 , and (D) with tripeptide 98 bearing pinacol protected 4-borono-L-phenylalanine.

Doan et al. reported the solid-phase derivatization of an enkephalin-like octapeptide sequence 96 (Figure 14C) [157]. The peptide, prepared on Wang resin, was modified using a variety of bases, solvents, catalysts and temperatures. Based on earlier reports on the instability of resin-bound peptides with unprotected $N$-termini [153], the final amino acid was introduced with a Boc protecting group. In their hands, aqueous solutions of weak bases $\left(\mathrm{K}_{3} \mathrm{PO}_{4}\right.$ or $\left.\mathrm{Na}_{2} \mathrm{CO}_{3}\right)$ in combination with DMF as solvent proved to be optimal. It was also found that the use of $\mathrm{Pd}\left(\mathrm{PPh}_{3}\right)_{4}$ as catalyst at a maximum 
temperature of $80{ }^{\circ} \mathrm{C}$ for $20 \mathrm{~h}$ provided access to a range of biaryl containing peptides 97. Not surprisingly, low yields were obtained upon insertion of several heteroaryl moieties, and significant side products were formed upon prolonged exposure to high temperature $\left(>100^{\circ} \mathrm{C}\right)$.

Interestingly, Afonso et al. disclosed for the first time the preparation of biaryl-containing peptides from 4-iodophenylalanine by sequential solid-phase borylation and Suzuki-Miyaura conversion [158]. Their approach relied on the introduction of the arylboron group by Miyaura borylation on Rink Amide resin. Treatment of polymer-bound halogenated peptide with the optimized catalytic conditions, being $\mathrm{B}_{2} \mathrm{pin}_{2} / \mathrm{KOAc} / \mathrm{PdCl}_{2}$ (dppf) in DMSO, afforded the boronopeptidyl resin 98 (Figure 14D) with excellent conversion, as determined by HPLC after small scale cleavage. Next, the cross-coupling was investigated with iodobenzene in degassed DMF under microwave irradiation. Initially, only minor conversions were attained, and side products, including deborylated or homocoupled peptide, were formed. By switching the solvent system to DME/EtOH/ $\mathrm{H}_{2} \mathrm{O}$ 9:9:2, in combination with the use of an aqueous solution of $\mathrm{K}_{3} \mathrm{PO}_{4}$, improved reaction efficiency was obtained, and gratifyingly, target arylated peptides 99 were accessed in acceptable isolated yields. In an extension of their work in solution phase [93], Cerezo reported the first solid-phase derivatization of 5-bromohistidine containing tripeptides (not shown) [159]. The 5-bromo-histidine residue was introduced as the $\mathrm{N}$-terminal amino acid via SPPS on Rink MBHA resin and subjected to Suzuki-Miyaura reactions. The imidazole moiety was protected with a SEM-group (as in Figure 5B). In comparison with their optimal solution-phase conditions, elevated temperatures $\left(170^{\circ} \mathrm{C}\right)$ and a solvent change to $\mathrm{DME} / \mathrm{H}_{2} \mathrm{O} / \mathrm{MeOH}$ was required.

\section{Formation of Biaryl-Bridges in Peptidic Natural Products and Peptide Macrocyclics}

By introduction of halogen and boron groups onto amino acid side chains, the preparation of biaryl products starting from two amino acids can be envisaged (see Section 2.3). First reports of these biaryl linkages in cyclic structures via Suzuki-Miyaura reactions were inspired on peptidic natural molecules such as complestatin. Elder and coworkers synthesized a model ring system 105 based on complestatin [160]. In their work, two syntheses are reported, going either via intramolecular cross-coupling of 103, containing brominated tryptophan and borylated tyrosine residues (Figure 15A) or via lactamization of a biaryl-bridged intermediate 104. The D-tryptophan residue in $\mathbf{1 0 3}$ and $\mathbf{1 0 4}$ was prepared via a key enantioselective ene-reaction between $\mathbf{1 0 0}$ and 101 with (S)-(-)-2,2'-p-tolyl-phosphino)-1,1'-binaphthyl ((S)-Tol-BINAP). The unnatural protected amino acid 102 was obtained in excellent ee (94\%). After peptide assembly in solution, 103 was submitted to Suzuki-Miyaura coupling condition (Figure 15A, reaction parameters not fully disclosed). Alternatively, the 17-membered ring system in $\mathbf{1 0 5}$ could be formed by activation of $\mathbf{1 0 4}$ with pentafluorophenyl diphenylphosphinate (FDPP) in diluted DMF.

The synthesis of biphenomycin analogue 107 was reported by Carbonnelle et al. Instead of isolating the pinacolatoboron intermediate, the diiodinated ortho-substituted Compound 106 was converted to biaryl 107 in a tandem procedure with $\mathrm{B}_{2} \mathrm{pin}_{2}$ and $\mathrm{PdCl}_{2}(\mathrm{dppf}$ ) (Figure 15B) [161]. The efficiency of such a tandem reaction was, however, moderate and highly dependent on the concentration of the reaction, with significant formation of de-iodinated compound. The interest of the Zhu group in the use of Suzuki-Miyaura reactions for natural product synthesis was further illustrated by the synthesis of RP-66453 108 [162], and the concise asymmetric total synthesis of biphenomycin B, wherein this cross-coupling served as the final step [107]. A different approach was reported by Waldmann et al. [163]. Here, the biaryl bridge in $\mathbf{1 0 8}$ was first prepared via intermolecular Suzuki-Miyaura of a pinacolatoboron- and iodo-precursor. The cyclization was then performed by lactamization, to again provide 108. Owing to their widespread occurrence in nature [61] and the efficient access of biaryl-bridged peptides via Suzuki-Miyaura cross-couplings, multiple research teams focused their efforts on natural product synthesis of, among others, TMC-95A/B 109a,b [164-168], arylomycins 110a,b [169], complestatin [170,171] and Rubiyunnanin B [172], wherein the Suzuki-Miyaura reaction often serves as the disconnection site of the biaryl-bridge (Figure 15C). 


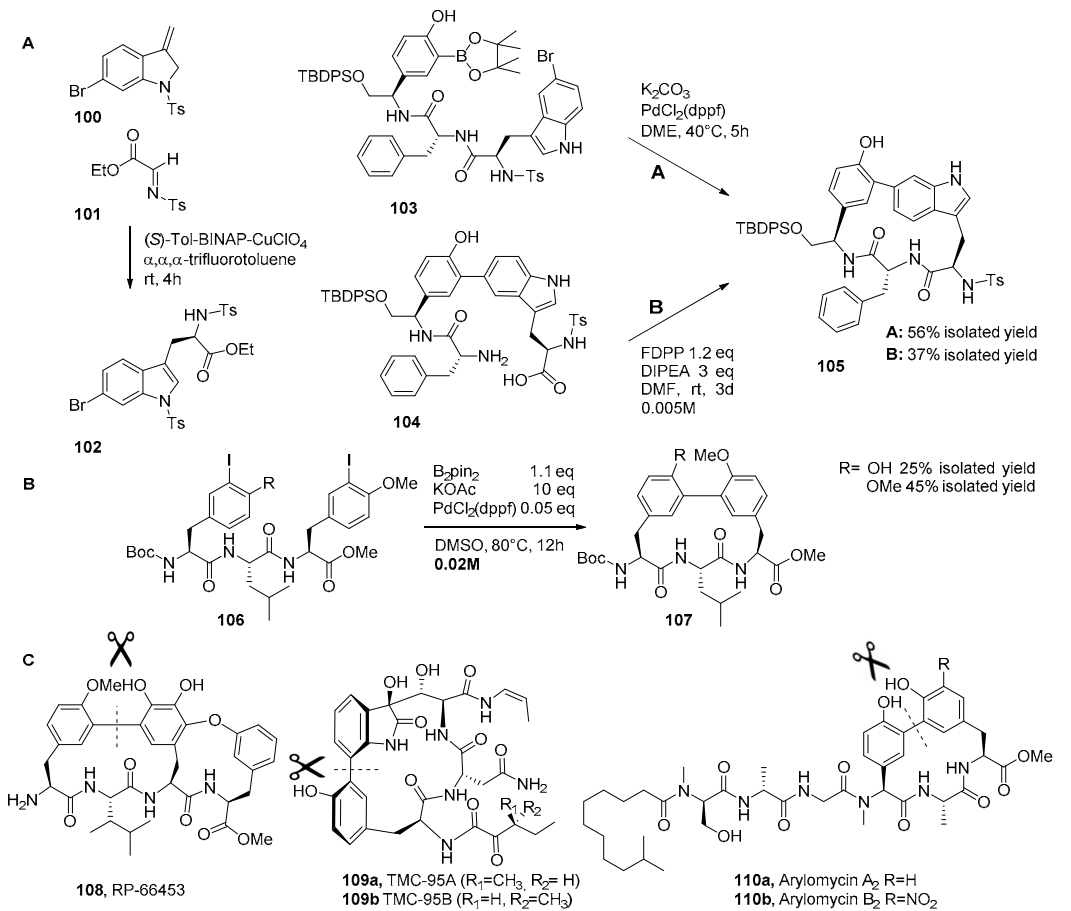

Figure 15. Cyclic peptide synthesis via Suzuki-Miyaura reactions. (A) Synthesis of a part of the ring system of complestatin (B), 105. One-pot borylation - Suzuki-Miyaura on diiodinated substrate 106. (C) Disconnection strategy for different natural products 108-110, bearing a biaryl bridge.
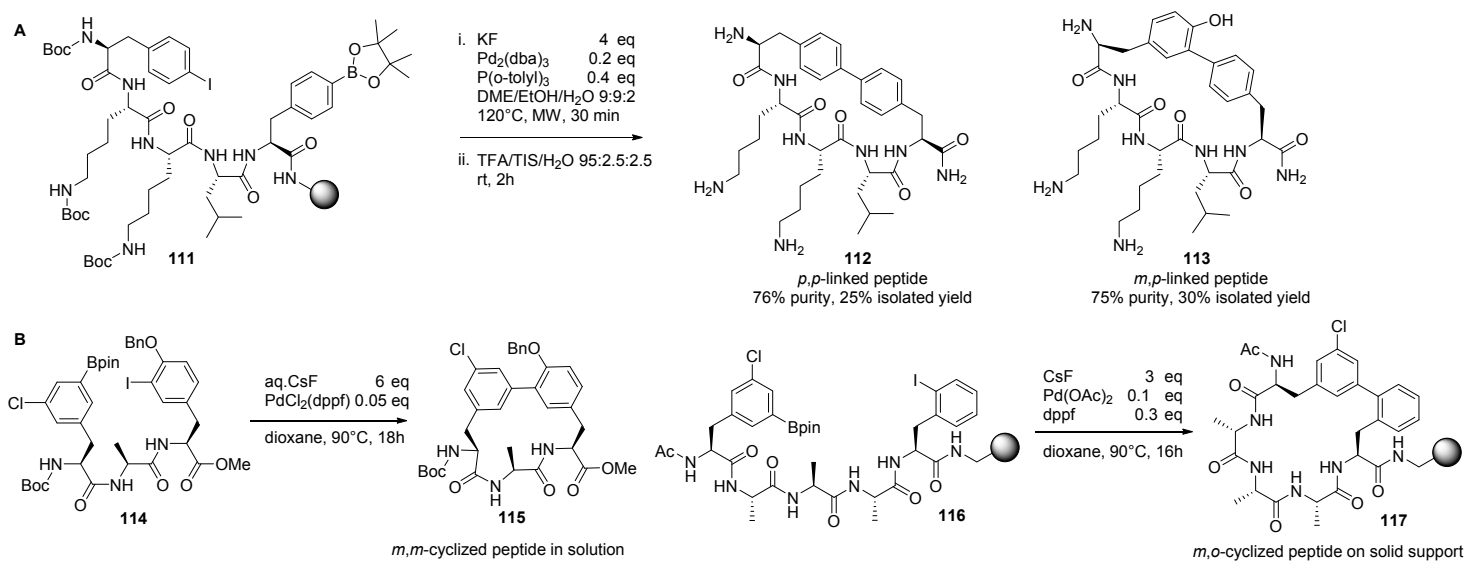

Figure 16. (A) Solid-phase synthesis of biaryl-linked peptide 112 with $p, p$-motif and 113 with $m, p$-motif. (B) Synthesis of $m, m$ - and $m, o$-cyclic peptide 115 and 117 via respective solution-phase and solid-phase Suzuki-Miyaura.

Afonso et al. extended their work on cross-couplings of borylated peptides on solid support [158] through the cyclization of a linear peptide, for example, 111, containing both the boronate and the halogenated aromatic amino acid [120]. Different ring sizes were obtained by varying both the length of the peptide sequence (three to eight residues) and the position of the halogen atom on the $N$-terminal amino acid ( $p$-I-Phe, $m$-I-Tyr and 3-Br-His). The cyclization was carried out under microwave conditions and provided the expected biaryl cyclic peptides in high purity for both $p, p$ and $m, p$-linked peptides as exemplified by, respectively, 112 and 113 in Figure 16A. An extension to their study was performed by alteration of the borylated residue [173]. The peptidyl resin containing protected 3-iodotyrosine was first borylated; and, after extension of the peptide chain, either protected 4-iodophenylalanine or 3-iodotyrosine was added to synthesize the $p, m$ - and $m, m$-crosslinked biaryl 
peptides (not shown). Meyer et al. report the preparation of additional combinations of biaryl-bridged peptides [174]. Either a solid- or solution-phase approach allowed $m, m-, o, m-$, and $m, o$-bridged cyclic peptides, for example, 115 and 117, through regiochemical variation of the aryl halide and arylboronate (Figure 16B). While solution-phase couplings were reported with $\mathrm{PdCl}_{2}$ (dppf) precatalyst, the solid-phase reactions were performed with $\mathrm{Pd}(\mathrm{OAc})_{2}$ and dppf.

\section{Protein Derivatization}

Substrate complexity was pushed further and proteins bearing halogenated or borylated amino acid side chains were considered. Labeling of protein substrates through natural amino acids side chains is commonly carried out on cysteine, lysine or even aspartic acid side chains [31,175]. However, the abundance of nucleophilic groups in proteins hampers site-specific alteration of the substrates and emphasized the necessity for a chemoselective reaction toolbox. For this purpose, chemoselective bioorthogonal reactions have been explored and exploited for labeling substrates such as peptides and proteins, but these conversions have also been used for other purposes, namely to change the pharmacokinetic and pharmacodynamic properties of biologically relevant peptides and proteins [29-33]. Popular bioorthogonal reactions examples include the Staudinger ligation, click chemistry, cycloadditions, and transition-metal catalyzed C-C bond formation. Of interest to this work, the potential of palladium-mediated chemistry has even been extended to living cells [176-178]. However, in case of transformations on highly complex proteins, containing multiple complexation sites, superstoichiometrical quantities (often palladium $>50 \mathrm{eq}$, boronic acid $>500 \mathrm{eq}$ ) are required. Since the allowed palladium level thresholds in active pharmaceutical ingredients are very low and metal impurities can affect activity and toxicity studies of the target compounds, analysis and removal of palladium impurities is of utmost importance [179]. Due to the scale of all described reactions (R\&D phase), recycling of the precious metal catalysts has not been studied in much detail when working on protein substrates. An exception to this can be found in the work of Dumas, which shows that inductively coupled plasma (ICP) with optical emission spectrometry (OES) can provide quantitative data on palladium content in protein samples after Suzuki-Miyaura reaction [34]. The addition of 3-mercaptopropionic acid has been shown to efficiently remove palladium from the protein surface [180]. Furthermore, recoverable palladium nanoparticles have been shown to possess excellent catalytic activity for the transformation of brominated or iodinated amino acids [145]. However, in view of future upscaling efforts, recyclability will have a major impact on newly developed methodologies $[179,181]$. Recent reviews on sustainable Suzuki-Miyaura reactions in aqueous media discuss the use of recoverable catalysts, yet these are limited to non-peptidic substrates $[11,138,182]$. In this respect, several recyclable catalysts [183-190], including silica- or polymer-supported catalysts and magnetically recoverable catalysts, are reported for biaryl formation and could potentially be implemented for transformations of peptide substrates.

Site-specific carbon-carbon bond formation on proteins was first realized by Kodama through Mizoroki-Heck and Sonogashira reactions on a His 6 -fused Ras protein containing a 4-iodophenylalanine residue (iF32-Ras-His) [65,82]. The first example of a Suzuki-Miyaura reaction on protein substrates was reported by Brustad and coworkers via expansion of the genetic code, which allowed selective introduction of a 4-boronophenylalanine residue [83]. Subsequently, the Suzuki-Miyaura reaction induced the coupling of a fluorescent iodoaryl boron-dipyrromethene (bodipy-I) scaffold through use of $\mathrm{Pd}_{2}(\mathrm{dba})_{3}$ complex in an aqueous buffered solution (20 mM EPPS) at $70{ }^{\circ} \mathrm{C}$, though in a moderate conversion (ca. 30\%) (Figure 17A). Both bodipy-I and $\mathrm{Pd}_{2}(\mathrm{dba})_{3}$ were added in 20-fold excess with respect to the borylated protein. Chalker et al. previously showed that an aqueous catalyst solution of the sodium salt of 2-amino-4,6-dihydroxypyrimidine (ADHP, 80a) and $\mathrm{Pd}(\mathrm{OAc})_{2}$ catalyzed cross-couplings in excellent yields on $C$-terminally unprotected amino acids using only buffered aqueous conditions at $37^{\circ} \mathrm{C}$ (vide supra, Section 2.4) [63]. Their elegant method was extended towards protein-based substrates by introduction of $p$-iodobenzyl cysteine (Pic) as replacement of a single cysteine residue in a subtilisin Bacillus lentus (SBL) mutant S156C 
(SBL-156ArI, Figure 17B) [63]. To ensure fast couplings, an excess of the catalyst solution (50 eq) and boronic acid (500 eq) were employed. Further research by the Davis group also showed that when 4-iodophenylalanine is present in a $\mathrm{His}_{6}$-tagged maltose binding protein (MBP), the ADHP-Pd(OAc) combination was again perfectly suited for the envisaged derivatization [180]. Similarly, 50 eq of palladium catalyst and 680 eq of boronic acid were required for achieving complete conversion after $2 \mathrm{~h}$ at $37^{\circ} \mathrm{C}$. Reaction follow-up by mass spectrometry was however hampered by non-specific metal binding to the protein. Therefore, the addition of 3-mercaptopropionic acid scavenger was mandatory to remove palladium and re-emergence of proteinogenic ionic species during MS reaction analysis. Spicer et al. expanded the scope of the Suzuki-Miyaura reaction to living cell surface proteins [191]. Four mutant plasmids of the OmpC protein were co-transformed into E. coli cells to incorporate 4'-iodo-L-Phe, via amber stop codon suppression, in different loop regions of cell-surface channels. The $\mathrm{Pd}(\mathrm{OAc})_{2}$. $(\mathrm{ADHP})_{2}$ catalyst system proved again appropriate for efficient labeling with fluorescent dyes on the outside of the cell-surface.

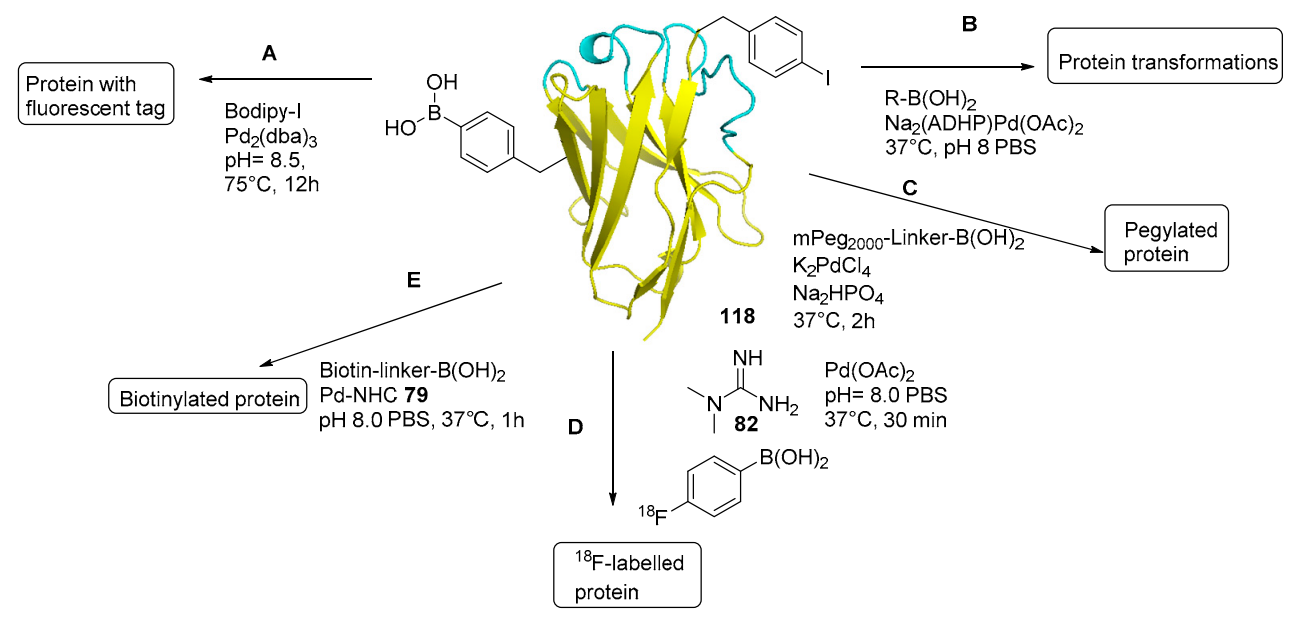

Figure 17. Schematic representation of different strategies for Suzuki-Miyaura reaction on protein substrates. Various proteins were utilized. Here, a common "dummy" substrate $\mathbf{1 1 8}$ is shown for illustrative purposes. (PBS = phosphate buffer).

Attachment of polyethylene glycol (PEG) chain to proteins (also denoted as the "PEGylation" process) in often used to improve stability and pharmacokinetic properties [192]. As a disadvantage, PEG-conjugates cope with a reduced biological activity which is related to the presence of multiple reactive sites at the level of amino acid side chain in the protein (usually lysine or cysteine residues). Therefore, the site-selective PEGylation via Suzuki-Miyaura reactions was envisaged as an alternative approach by Dumas (Figure 17C) [34]. A PEG unit (2 kDa or $20 \mathrm{kDa}$ ) was attached to two different iodinated proteins (Np $\beta-69$ pIPhe and SBL-156Pic). First, the derivatization of Boc-4-iodophenylalanine was unsuccessfully attempted with a monomethoxy PEG polymer phenylboronic acid (mPEG-PBA) reagent and ADHP as the ligand. Luckily, upon application of structurally related ligands such as 2-(N,N)-dimethyl-4,6-dihydroxypyrimidine ( $N, N$-diMeADHP) and methylated guanidine derivatives, the derivatizations proceeded smoothly after $2 \mathrm{~h}$ at $37^{\circ} \mathrm{C}$. Intriguingly, reaction conversion also proceeded in $>90 \%$ conversion when no ligand was added to reactions with $\mathrm{K}_{2} \mathrm{PdCl}_{4}$ as the palladium source. Converting these findings on the iodinated proteins showed that these "self-liganded" conditions resulted in high conversion for both Np $\beta-69$ pIPhe and SBL-156Pic with respectively 40 and $10 \mathrm{eq}$ of Pd catalyst and $1000 \mathrm{eq}$ of the $\mathrm{mPEG}_{2 \mathrm{k}}$-PBA (Figure 17C). Application of the guanidine-based ligands was furthermore explored for the introduction of ${ }^{18} \mathrm{~F}$ tags by Gao et al. [142]. With 1,1-dimethylguanidine 82 as a ligand, the first Pd-catalyzed introduction of ${ }^{18} \mathrm{~F}$, the most common radionuclide in PET imaging, was exemplified on SBL-156Pic (Figure 17D) with 250 eq of Pd-catalyst solution and 250 eq of labeled 4-fluorophenylboronic acid. Moreover, Ma and coworkers have 
shown that water-soluble NHCs, such as $\mathbf{7 9}$ (Figure 12), can be applied for protein derivatizations (Figure 17E) [135]. Pd-complexes with NHC-ligands bearing hydrophilic groups were first verified on $\mathrm{N}$-Boc-4-iodophenylalanine under mild conditions $\left(37^{\circ} \mathrm{C}, 2-6 \mathrm{~h}\right)$. The feasibility of this methodology was transferred to a modified Bovine serum albumin (BSA) protein (not shown). In this study, the introduction of the halogen moiety was realized by derivatization of the lysine residues with ( $p$-iodophenyl)methyl $p$-nitrophenyl carbonate. Incubation of the iodine-bearing protein $p$ IPM-BSA with 100 eq of this Pd-NHC complex and 100 eq of biotin- $\mathrm{B}(\mathrm{OH})_{2}$ yielded the desired derivatives (Figure 17E). Similarly, a lysozyme containing $p$-iodobenzoate ( $p$ IBZ-lyso) also underwent efficient cross-coupling with a PEG-bearing boronic acid (not shown) [135]. The utility of this catalytic system was even demonstrated to work on the cell-surface of live mammalian cells. Biotinylation of HeLa cells, pretreated with $\mathrm{N}$-succinimidyl $p$-iodobenzoate, was achieved as detected by confocal microscopy. Interestingly, clearly, the high versatility of the Suzuki-Miyaura reaction is demonstrated by successful conversions on the abovementioned and highly challenging substrates.

\section{The Suzuki-Miyaura Reaction as a Tool towards Improved Biological Activity}

Most of the successful drugs can be subdivided in "small molecules" (MW < 500) and "biologicals" $(\mathrm{MW}>5000)$. The latter class has emerged during the last decades due in part to an improved knowledge of recombinant protein expression and purification. These biomolecules often possess excellent biological activity and selectivity, but they are not amenable to oral bioavailability and come with a high production cost. Up until the past two decades, the large gap between these two classes had been less explored by the pharmaceutical industry. However, peptides of short and intermediate length $(<50 \mathrm{AA})$ lie in the soft spot between small molecules and biologicals $[45,193]$. They still possess the high specificity for their biological target (which reduces the risk for off-target effects) and they can be made by synthetic organic chemistry. However, if we consider linear peptides bearing natural side chains, several inherent drawbacks arise. When comparing to typical "small molecules," disadvantages of these small peptides include poor metabolic stability, low (oral) bioavailability, and rapid clearance rates. In this regard, the Suzuki-Miyaura reaction provides a valuable bioorthogonal reaction to the medicinal chemist, as both the introduction of non-natural amino acids and a reduction of side chain flexibility can be realized via this reaction. Biaryl adducts have provided valuable SAR-information and proved to alter the selectivity, stability, and availability of the parent peptide. Selected examples to illustrate this are touched upon below.

The groups of Hagmann and Yang described the optimization of sulfonylated dipeptide inhibitors with subnanomolar inhibitory activity for integrin VLA-4 as illustrated by compound 119. [194,195]. Highly potent analogues, for example, 120 and $\mathbf{1 2 1}$ (Figure 18A), were obtained when encompassing a biarylic $C$-terminal residue. Modification of the substituents on the distal ring of biphenylalanine altered the availability, half-life and clearance rate of the dipeptide ligands. Synthesis of these ligands was carried out by Suzuki-Miyaura reaction on the protected triflated tyrosine [194] or halogenated phenylalanine [195] with $\mathrm{Pd}\left(\mathrm{PPh}_{3}\right)_{4}$ in toluene and the corresponding boronic acids to yield $\mathbf{1 2 0}$ and 121.

In analogy, dual $\alpha_{4} \beta_{1} / \alpha_{4} \beta_{7}$ integrin antagonists, for example, 122 and 124, were designed by Sircar and Castanedo (Figure 18B) [196,197]. Sircar and coworkers prepared ligand 122 via Suzuki-Miyaura-catalyzed cross-coupling of triflated tyrosine or bromophenylalanine with $\mathrm{Pd}\left(\mathrm{PPh}_{3}\right)_{4}$ in DME [196]. Castanedo prepared the ligands via on-resin derivatization with $\mathrm{PdCl}_{2}$ (dppf) in NMP [197]. Exploration of the chemical space surrounding the distal ring of the biphenylalanine moiety indicated that substitution of the ortho-position had a beneficial effect on the inhibitory activity.

Short analogues of Glucagon-like peptide 1 (GLP-1) with potential antidiabetic activity were prepared by Mapelli (Figure 18C) [198]. The natural gastrointestinal peptide hormone exists predominantly as a 30 or 31 amino acid sequence with functional agonist activity at the GLP-1 G protein-coupled receptor. Endogenous GLP-1 is not suitable as a therapeutic agent due to its very short half-life time of ca. $2 \mathrm{~min}$. A lead nonapeptide containing the critical residues for binding was extended 
with two biphenyl residues, to yield an 11-mer peptide 125. The presence of two biphenylalanine moieties was found to be crucial for providing submicromolar agonist activity in the utilized cAMP accumulation assay. Introduction of small substituents on the distal rings of the biphenylalanines further improved the biological activity ( $\mathrm{EC}_{50}$ decreased to $7 \mathrm{nM}$, not shown). Additionally, alterations to the initial 9-mer showed a significant improvement in activity $(0.087 \mathrm{nM})$ and resulted in a nearly equipotent analogue 126, as compared to the endogenous 30-mer, while prolonging the in vivo residence time to $20 \mathrm{~h}$. Introduction of side chain-based macrocyclic constraints by lactam formation as illustrated in $\mathbf{1 2 7}$ or disulfide linkage in $\mathbf{1 2 8}$ produced agonists with stabilized secondary structural motifs ( $N$-terminal $\beta$-turn and $C$-terminal helix) that differentially influenced affinity and agonist potency [199]. Both Mapelli and Hoang reported the synthesis of the unusual biaryl building blocks via attachment of 4-iodophenylalanine to the solid-support, followed by Suzuki-Miyaura reaction with the respective boronic acids and $\mathrm{Pd}\left(\mathrm{PPh}_{3}\right)_{4}$ or $\mathrm{Pd}(\mathrm{OAc})_{2}$ and JohnPhos.
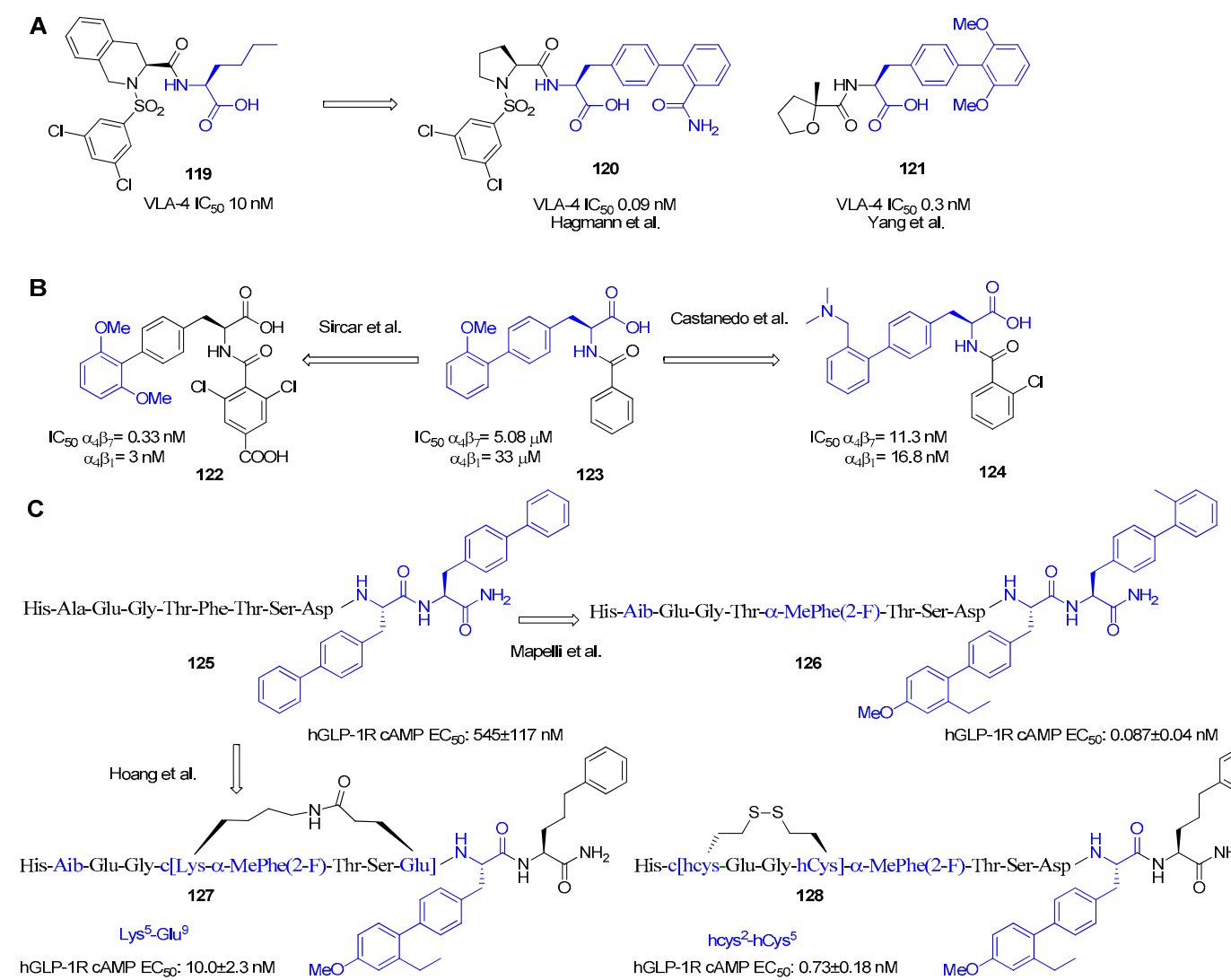

Figure 18. (A) Synthesis of dipeptide ligands $\mathbf{1 2 0}$ and $\mathbf{1 2 1}$ with inhibitory activity for integrin VLA-4. (B) Dual $\alpha_{4} \beta_{1} / \alpha_{4} \beta_{7}$ integrin antagonists 122 and 124. (C) Short GLP-1 analogues 126-128 that are improved by amino acid substitution (126) and introduction of secondary motifs by backbone cyclization (127 and 128).

Cationic antimicrobial peptides (CAP) have been studied as a therapeutic alternative to the widespread bacterial resistance of common antibiotics. Typically, the sequences of these amphipathic peptides alternate between cationic residues and hydrophobic moieties. The positive influence of bulky hydrophobic groups has been described in these CAPs [200]. Evidently, biaryl containing peptides 129 and 130 were explored for their activity versus Gram-positive drug-resistance pathogenic bacteria (Figure 19A) [156,201]. In view of the development of novel antimicrobial peptides, $\mathrm{Ng}$-Choi et al. incorporated 5-bromohistidine as a replacement of phenylalanine in undecapeptides at the 1- or 4-position (for example, 131, Figure 19B) [202]. Derivatization of these building blocks was previously reported on solid-phase [159] and afforded a small library of biaryl peptides, which were 
tested for their biological activity in comparison with the lead peptide H-FKLFKKILKFL-NH $\mathrm{N}_{2}$. These arylhistidine-containing peptides displayed similar antibacterial and antifungal activity; however, a decreased hemolytic effect was observed. Hemolysis represents an important concern when developing CAPs.
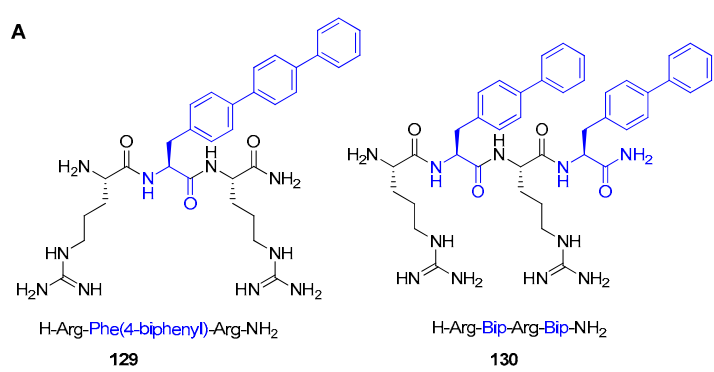

B

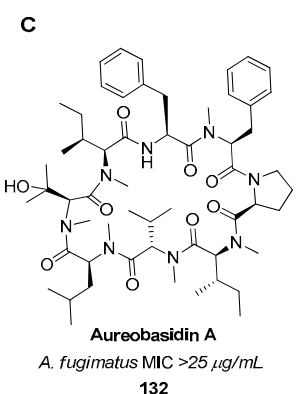

130
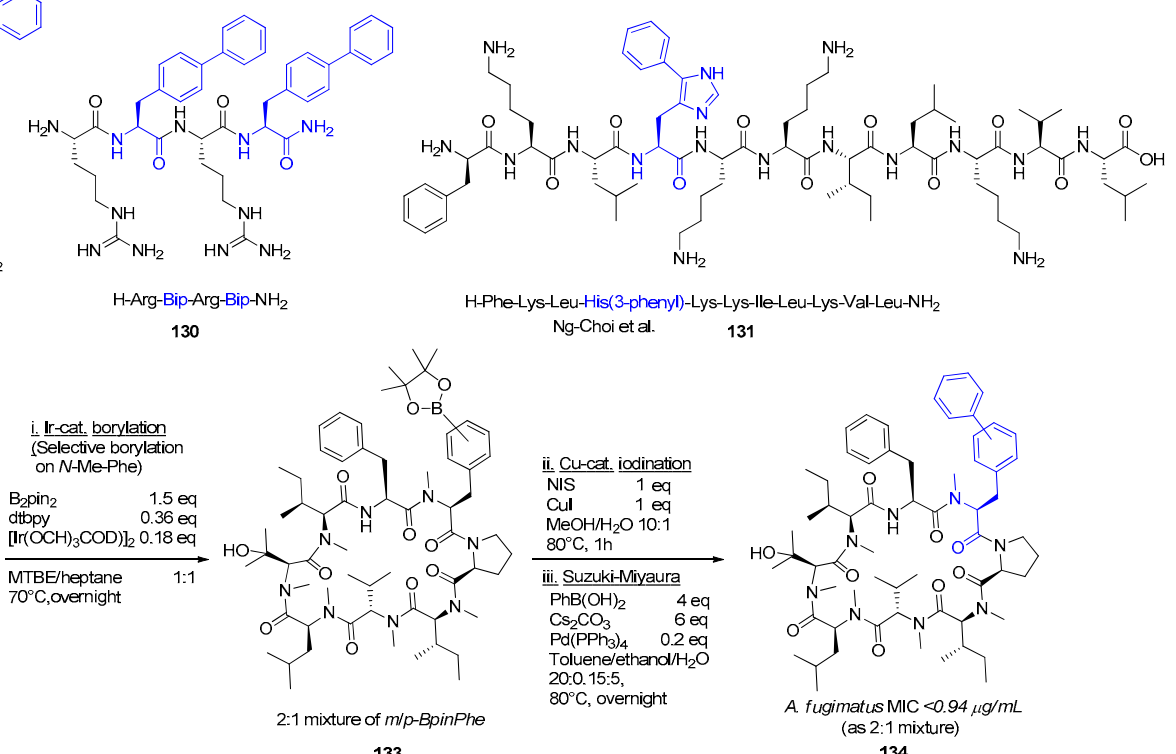

Figure 19. (A) Short cationic antimicrobial peptides $\mathbf{1 2 9}$ and $\mathbf{1 3 0}$ featuring, respectively, triaryl-and biarylphenylalanine (B) Improvement of the antimicrobial activity of undecapeptides by incorporation of 5-arylhistidine (C) Improvement of antifungal activity via borylation-Suzuki-Miyaura reaction on Aurebasidin A 134.

The Suzuki-Miyaura reaction has also proven useful in the optimization of cyclic peptides. Wuts et al. explored analogues of Aurebasidin A (AbA) as antifungal agent to improve potency against a human pathogen (Aspergillus fumigatus) [203]. Selective borylation of the $\mathrm{N}$-Me-Phe residue of $\mathbf{1 3 2}$ generated a 2:1 mixture of $m$ - and $p$-substituted phenylalanine that was converted to iodophenylalanine and submitted to Suzuki-Miyaura catalysis (Figure 19C). Substrate $\mathbf{1 3 4}$ was found to be a potent ligand with an enhanced minimal inhibitory concentration (MIC) value, as compared to the native AbA.

\section{Conclusions}

In this review, we covered the initial developments of Suzuki-Miyaura cross-couplings on single amino acids in organic(/aqueous) media up to aqueous reaction conditions for the efficient derivatization of complex protein substrates. A plethora of unusual biaryl substituted amino acids was made accessible through this reaction, starting from either halogenated or borylated residues. Initial work was primarily focused on organic media with typical catalysts $\left(\mathrm{Pd}\left(\mathrm{PPh}_{3}\right)_{4}, \mathrm{Pd}(\mathrm{OAc})_{2}\right.$, $\left.\mathrm{Pd}_{2}(\mathrm{dba})_{3}\right)$, to provide protected amino acids. Progress towards (pre)catalysts that are active, stable and more soluble in aqueous environments and subjected to mild conditions enabled the derivatization of more complex substrates. Especially, water-soluble pyrimidine ligands and hydrophilic analogues of classic ligands ( $\mathrm{PPh}_{3}, \mathrm{NHC}$, SPhos) have made transformations in aqueous media possible. This allowed the late-stage derivatization of peptides, both in solution- and solid-phase, for multiple applications, such as drug discovery and labeling efforts. Furthermore, the constrained biaryl-bridge motif was introduced in peptidic natural products and peptide substrates, and led to cyclic analogues. Transformations on protein substrates were realized as well, albeit superstoichiometrical quantities are required for derivatization of these highly complex substrates. Interestingly, recyclability of the palladium catalysts or recoverability of palladium is typically not discussed yet, due to the small 
scale on which the cross-couplings have been executed. Furthermore, catalyst development is still required to achieve higher substrate compatibility and a more broadly applicable catalyst system. Current limitations include the incompatibility of cross-couplings with alkylboronic acids and the limited use of chlorinated substrates. Nevertheless, it is clear that the Suzuki-Miyaura reaction is a powerful tool for the bioorthogonal transformation of amino acid substrates, peptides, and proteins. The incorporation of biaryl-bridged amino acids has been shown to significantly impact the biological activity of peptide sequences, and further development in the field of Suzuki-Miyaura catalysis will definitely have a positive impact on both synthetic methodology and pharmaceutical applications.

Acknowledgments: We gratefully acknowledge the IWT Flanders and Janssen Pharmaceutica for financial support of T.W. This work is supported by the Scientific Research Network (WOG) "Sustainable chemistry for the synthesis of fine chemicals" of the Research Foundation - Flanders (FWO).

Conflicts of Interest: The authors declare no conflict of interest.

\section{References}

1. Miyaura, N.; Suzuki, A. Palladium-Catalyzed Cross-Coupling Reactions of Organoboron Compounds. Chem. Rev. 2015, 95, 2457-2483. [CrossRef]

2. Suzuki, A. Cross-Coupling Reactions of Organoboranes: An Easy Way to Construct C-C Bonds (Nobel Lecture). Angew. Chem. Int. Ed. 2011, 50, 6722-6737. [CrossRef] [PubMed]

3. Genet, J.-P.; Savignac, M. Recent developments of palladium(0) catalyzed reactions in aqueous medium. J. Organomet. Chem. 1999, 576, 305-317. [CrossRef]

4. Lennox, J.J.; Lloyd-Jones, G.C. Preparation of Organotrifluoroborate Salts: Precipitation-Driven Equilibrium under Non-Etching Conditions. Angew. Chem. Int. Ed. 2012, 51, 9385-9388. [CrossRef] [PubMed]

5. Darses, S.; Genet, J.-P. Potassium Organotrifluoroborates: New Perspectives in Organic Synthesis. Chem. Rev. 2008, 108, 288-325. [CrossRef] [PubMed]

6. Knapp, D.M.; Gillis, E.P.; Burke, M.D. A General Solution for Unstable Boronic Acids: Slow-Release Cross-Coupling from Air-Stable MIDA Boronates. J. Am. Chem. Soc. 2009, 131, 6961-6963. [CrossRef] [PubMed]

7. Molander, G.A.; Ellis, N. Organotrifluoroborates: Protected Boronic Acids That Expand the Versatility of the Suzuki Coupling Reaction. Acc. Chem. Res. 2007, 40, 275-286. [CrossRef] [PubMed]

8. Lennox, J.J.; Lloyd-Jones, G.C. Selection of boron reagents for Suzuki-Miyaura coupling. Chem. Soc. Rev. 2014, 43, 412-443. [CrossRef] [PubMed]

9. Hall, D.G. Structure, properties, and preparation of boronic acid derivatives. overview of their reactions and applications. In Boronic Acids: Preparation and Applications in Organic Synthesis and Medicine; Hall, D.G., Ed.; Wiley-VCH Verlag GmbH \& Co. KGaA: Weinheim, Germany, 2005; Volume 1, pp. 1-99.

10. Anderson, K.W.; Buchwald, S.L. General Catalysts for the Suzuki-Miyaura and Sonogashira Coupling Reactions of Aryl Chlorides and for the Coupling of Challenging Substrate Combinations in Water. Angew. Chem. Int. Ed. 2005, 44, 6173-6177. [CrossRef] [PubMed]

11. Polshettiwar, V.; Decottignies, A.; Len, C.; Fihri, A. Suzuki-Miyaura Cross-Coupling Reactions in Aqueous Media: Green and Sustainable Syntheses of Biaryls. ChemSusChem 2010, 3, 502-522. [CrossRef] [PubMed]

12. Shaugnessy, K.H. Cross-Coupling reactions in Aqueous Media. In Cross-Coupling Reactions in Aqueous Media, in Palladium-Catalyzed Coupling Reactions: Practical Aspects and Future Developments; Molnár, Á., Ed.; Wiley-VCH Verlag GmbH \& Co. KGaA: Weinheim, Germany, 2013; Volume 1, pp. 235-286.

13. Rossi, R.; Bellina, F.; Lessi, M.; Manzini, C.; Marianetti, G.; Perego, L.A. Recent Applications of Phosphane-based Palladium Catalysts in Suzuki-Miyaura Reactions Involved in Total Syntheses of Natural Products. Curr. Org. Chem. 2015, 19, 1302-1409. [CrossRef]

14. Nicolaou, K.C.; Bulger, P.G.; Sarlah, D. Palladium-Catalyzed Cross-Coupling Reactions in Total Synthesis. Angew. Chem. Int. Ed. 2005, 44, 4442-4489. [CrossRef] [PubMed]

15. Ronson, T.O.; Taylor, R.J.K.; Fairlamb, I.J.S. Palladium-Catalysed macrocyclisations in the total synthesis of natural products. Tetrahedron 2015, 71, 989-1009. [CrossRef]

16. Heravi, M.M.; Hashemi, E. Recent applications of the Suzuki reaction in total synthesis. Tetrahedron 2012, 68, 9145-9478. [CrossRef] 
17. Amann, N.; Wagenknecht, H.A. Preparation of pyrenyl-modified nucleosides via Suzuki-Miyaura cross-coupling reactions. Synlett 2002, 5, 687-691. [CrossRef]

18. Western, E.C.; Daft, J.R.; Johnson, E.M.; Gannett, P.M.; Shaughnessy, K.H. Efficient One-Step Suzuki Arylation of Unprotected Halonucleosides, Using Water-Soluble Palladium Catalysts. J. Org. Chem. 2003, 68, 6767-6774. [CrossRef] [PubMed]

19. Nencka, R.; Sinnaeve, D.; Karalic, I.; Martins, J.C.; Van Calenbergh, S. Synthesis of C-6-substituted uridine phosphonates through aerobic ligand-free Suzuki-Miyaura cross-coupling. Org. Biomol. Chem. 2010, 8, 5234-5246. [CrossRef] [PubMed]

20. Omumi, A.; Beach, D.G.; Baker, M.; Gabryelski, W.; Manderville, R.A. Postsynthetic Guanine Arylation of DNA by Suzuki-Miyaura Cross-Coupling. J. Am. Chem. Soc., 2011, 133, 42-50. [CrossRef] [PubMed]

21. Fresneau, N.; Hiebel, M.-A.; Agrofoglio, L.A.; Berteina-Raboin, S. Efficient Synthesis of Unprotected C-5-Aryl/Heteroaryl-2'-deoxyuridine via a Suzuki-Miyaura Reaction in Aqueous Media. Molecules 2012, 17, 14409-14417. [CrossRef] [PubMed]

22. De Ornellas, S.; Williams, T.J.; Baumann, C.G.; Fairlamb, I.J.S. Catalytic C-H/C-X bond functionalisation of nucleosides, nucleotides, nucleic acids, amino acids, peptides and proteins. In $\mathrm{C}-\mathrm{H}$ and $\mathrm{C}-\mathrm{X}$ Bond Functionalization; Ribas, X., Ed.; Royal Society of Chemistry: Cambridge, UK, 2013; Volume 11, pp. $409-447$.

23. Herve, G.; Sartori, G.; Enderlin, G.; Mackenzie, G.; Len, C. Palladium-catalyzed Suzuki reaction in aqueous solvents applied to unprotected nucleosides and nucleotides. RSC Adv. 2014, 4, 18558-18594. [CrossRef]

24. Carrow, B.P.; Hartwig, J.F. Distinguishing Between Pathways for Transmetalation in Suzuki-Miyaura Reactions. J. Am. Chem. Soc. 2011, 133, 2116-2119. [CrossRef] [PubMed]

25. Amatore, C.; Jutand, A.; Le Duc, G. Kinetic Data for the Transmetalation/Reductive Elimination in Palladium-Catalyzed Suzuki-Miyaura Reactions: Unexpected Triple Role of Hydroxide Ions Used as Base. Chem. Eur. J. 2011, 17, 2492-2503. [CrossRef] [PubMed]

26. Amatore, C.; Le Duc, G.; Jutand, A. Mechanism of Palladium-Catalyzed Suzuki-Miyaura Reactions: Multiple and Antagonistic Roles of Anionic "Bases" and Their Countercations. Chem. Eur. J. 2013, 19, 10082-10093. [CrossRef] [PubMed]

27. Lennox, A.J.J.; Lloyd-Jones, G.C. Organotrifluoroborate Hydrolysis: Boronic Acid Release Mechanism and an Acid-Base Paradox in Cross-Coupling. J. Am. Chem. Soc. 2012, 134, 7431-7441. [CrossRef] [PubMed]

28. Lennox, A.J.J.; Lloyd-Jones, G.C. Transmetalation in the Suzuki-Miyaura Coupling: The Fork in the Trail. Angew. Chem. Int. Ed. 2013, 52, 7362-7370. [CrossRef] [PubMed]

29. Lang, K.; Chin, J.W. Bioorthogonal Reactions for Labeling Proteins. ACS Chem. Biol. 2014, 9, 16-20. [CrossRef] [PubMed]

30. King, M.; Wagner, A. Developments in the Field of Bioorthogonal Bond Forming Reactions-Past and Present Trends. Bioconj. Chem. 2014, 25, 825-839. [CrossRef] [PubMed]

31. Spicer, C.D.; Davis, B.G. Selective chemical protein modification. Nat. Commun. 2014, 5, 4740-4753. [CrossRef] [PubMed]

32. Sletten, M.; Bertozzi, C.R. Bioorthogonal Chemistry: Fishing for Selectivity in a Sea of Functionality. Angew. Chem. Int. Ed. 2009, 48, 6974-6998. [CrossRef] [PubMed]

33. Chen, X.; Wu, Y.-W. Selective labelling of proteins. Org. Biomol. Chem. 2016, 14, 5417-5439. [CrossRef] [PubMed]

34. Dumas, A.; Spicer, C.D.; Gao, Z.; Takehana, T.; Lin, Y.A.; Yasukohchi, T.; Davis, B.G. Self-Liganded Suzuki-Miyaura Coupling for Site-Selective Protein PEGylation. Angew. Chem. Int. Ed. 2013, 52, 3916-3921. [CrossRef] [PubMed]

35. Keller, S.; Wage, T.; Hohaus, K.; Hölzer, E.E.; van Pée, K.-H. Purification and Partial Characterization of Tryptophan 7-Halogenase (PrnA) from Pseudomonas fluorescens. Angew. Chem. Int. Ed. 2000, 39, 2300-2302. [CrossRef]

36. Yeh, E.; Garneau, S.; Walsh, C.T. Robust in vitro activity of RebF and RebH, a two-component reductasehalogenase, generating 7-chlorotryptophan during rebeccamycin biosynthesis. Proc. Natl. Acad. Sci. USA 2005, 102, 3960-3965. [CrossRef] [PubMed]

37. Goss, R.J.M.; Newill, P.L.A. A Convenient Enzymatic Synthesis of L-halotryptophans. Chem. Commun. 2006, 47, 4924-4925. [CrossRef] [PubMed]

38. Smith, D.R.M.; Grüshow, S.; Goss, R.J.M. Scope and potential of halogenases in biosynthetic applications. Curr. Opin. Chem. Biol. 2013, 17, 276-283. [CrossRef] [PubMed] 
39. Kaiser, P.F.; Churches, Q.I.; Hutton, C.A. Organoboron Reagents in the Preparation of Functionalized

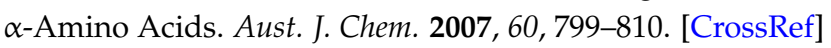

40. Sivaev, I.B.; Bregadze, V.I. L-4-Boronophenylalanine (all around the one molecule). ARKIVOC 2008, 47-61.

41. Moreira, I.S.; Fernandes, P.A.; Ramos, M.J. Hot spots-A review of the protein-protein interface determinant amino-acid residues. Proteins: Struct. Funct. Genet. 2007, 68, 803-812. [CrossRef] [PubMed]

42. Kotha, S.; Goyal, D.; Chavan, A.S. Diversity-Oriented Approaches to Unusual $\alpha$-Amino Acids and Peptides: Step Economy, Atom Economy, Redox Economy, and Beyond. J. Org. Chem. 2014, 78, 12288-12313. [CrossRef] [PubMed]

43. Stevenazzi, A.; Marchini, M.; Sandrone, G.; Vergani, B.; Lattanzio, M. Amino acidic scaffolds bearing unnatural side chains: An old idea generates new and versatile tools for the life sciences. Bioorg. Med. Chem. Lett. 2014, 24, 5349-5356. [CrossRef] [PubMed]

44. Blaskovich, M.A.T. Unusual Amino Acids in Medicinal Chemistry. J. Med. Chem. 2016, 59, 10807-10836. [CrossRef] [PubMed]

45. Fosgerau, K.; Hoffmann, T. Peptide therapeutics: current status and future directions. Drug Discov. Today 2015, 20, 122-128. [CrossRef] [PubMed]

46. Adessi, C.; Soto, C. Converting a Peptide into a Drug: Strategies to Improve Stability and Bioavailability. Curr. Med. Chem. 2002, 9, 963-978. [CrossRef] [PubMed]

47. Van der Poorten, O.; Knuhtsen, A.; Pedersen, D.S.; Ballet, S.; Tourwé, D. Side Chain Cyclized Aromatic Amino Acids: Great Tools as Local Constraints in Peptide and Peptidomimetic Design. J. Med. Chem. 2016, 59, 10865-10890. [CrossRef] [PubMed]

48. Marsault, E.; Peterson, M.L. Macrocycles Are Great Cycles: Applications, Opportunities, and Challenges of Synthetic Macrocycles in Drug Discovery. J. Med. Chem. 2011, 54, 1961-2004. [CrossRef] [PubMed]

49. White, C.J.; Yudin, A.K. Contemporary strategies for peptide macrocyclization. Nat. Chem. 2011, 3, 509-524. [CrossRef] [PubMed]

50. Martí-Centelles, V.; Pandey, M.D.; Burguete, M.I.; Luis, S.V. Macrocyclization Reactions: The Importance of Conformational, Configurational, and Template-Induced Preorganization. Chem. Rev. 2015, 115, 8736-8834. [CrossRef] [PubMed]

51. Yudin, A.K. Macrocycles: Lessons from the distant past, recent developments, and future directions. Chem. Sci. 2015, 6, 30-49. [CrossRef]

52. Lau, Y.H.; de Andrade, P.; Wu, Y.; Spring, D.R. Peptide stapling techniques based on different macrocyclisation chemistries. Chem. Soc. Rev. 2015, 44, 91-102. [CrossRef] [PubMed]

53. Góngora-Benítez, M.; Tulla-Puche, J.; Albericio, F. Multifaceted Roles of Disulfide Bonds. Peptides as Therapeutics. Chem. Rev. 2014, 114, 901-926. [CrossRef] [PubMed]

54. Gleeson, E.C.; Roy Jackson, W.; Robinson, A.J. Ring-Closing metathesis in peptides. Tetrahedron Lett. 2016, 57, 4325-4333. [CrossRef]

55. Ahmad Fuaad, A.A.H.; Azmi, F.; Skwarczynski, M.; Toth, I. Peptide Conjugation via CuAAC 'Click' Chemistry. Molecules 2013, 18, 13148-13174. [CrossRef] [PubMed]

56. Dong, H.; Limberakis, C.; Liras, S.; Price, D.; James, K. Peptidic macrocyclization via palladium-catalyzed chemoselective indole C-2 arylation. Chem. Commun. 2012, 48, 11644-11646. [CrossRef] [PubMed]

57. Hopkins, B.A.; Smith, G.F.; Sciammetta, N. Synthesis of Cyclic Peptidomimetics via a Pd-Catalyzed Macroamination Reaction. Org. Lett. 2016, 18, 4072-4075. [CrossRef] [PubMed]

58. Makwana, K.M.; Mahalakshmi, R. Trp-Trp Cross-Linking: A Structure-Reactivity Relationship in the Formation and Design of Hyperstable Peptide $\beta$-Hairpin and $\alpha$-Helix Scaffolds. Org. Lett. 2014, 17, 2498-2501. [CrossRef] [PubMed]

59. Mendive-Tapia, L.; Preciado, S.; Garciá, J.; Ramón, R.; Kielland, N.; Albericio, F.; Lavilla, R. New peptide architectures through $\mathrm{C}-\mathrm{H}$ activation stapling between tryptophan-phenylalanine/tyrosine residues. Nat. Comm. 2015, 6, 7160. [CrossRef] [PubMed]

60. Lloyd-Williams, P.; Giralt, E. Atropisomerism, biphenyls and the Suzuki coupling: Peptide antibiotics. Chem. Soc. Rev. 2001, 30, 145-157. [CrossRef]

61. Feliu, L.; Planas, M. Cyclic Peptides Containing Biaryl and Biaryl Ether Linkages. Int. J. Pept. Res. Ther. 2005, 11, 53-97. [CrossRef]

62. Shaugnessy, K.H. Hydrophilic Ligands and Their Application in Aqueous-Phase Metal-Catalyzed Reactions. Chem. Rev. 2009, 109, 643-710. [CrossRef] [PubMed] 
63. Chalker, J.M.; Wood, C.S.C.; Davis, B.G. A Convenient Catalyst for Aqueous and Protein Suzuki-Miyaura Cross-Coupling. J. Am. Chem. Soc. 2009, 131, 16346-16347. [CrossRef] [PubMed]

64. Deb Roy, A.; Goss, R.J.M.; Wagner, G.K.; Winn, M. Development of fluorescent aryltryptophans by Pd mediated cross-coupling of unprotected halotryptophans in water. Chem. Commun. 2008, 39, 4831-4833.

65. Kodama, K.; Fukuzawa, S.; Nakayama, H.; Sakamoto, K.; Kigawa, T.; Yabuki, T.; Matsuda, N.; Shirouzu, M.; Takio, K.; Yokoyama, S.; et al. Site-Specific Functionalization of Proteins by Organopalladium Reactions. ChemBioChem 2007, 8, 232-238. [CrossRef] [PubMed]

66. Jackson, R.F.W.; Wishart, N.; Wood, A.; James, K.; Wythes, M.J. Preparation of Enantiomerically Pure Protected 4-Oxo- $\alpha$-amino Acids and 3-Aryl- $\alpha$-amino Acids from Serine. J. Org. Chem. 1992, 57, 3397-3404. [CrossRef]

67. Jackson, R.F.W.; Moore, R.J.; Dexter, C.S. Concise Synthesis of Enantiomerically Pure Phenylalanine, Homophenylalanine, and Bishomophenylalanine Derivatives Using Organozinc Chemistry: NMR Studies of Amino Acid-Derived Organozinc Reagents. J. Org. Chem. 1998, 63, 7875-7884. [CrossRef]

68. Ross, A.J.; Lang, H.L.; Jackson, R.F.W. Much Improved Conditions for the Negishi Cross- Coupling of Iodoalanine Derived Zinc Reagents with Aryl Halides. J. Org. Chem. 2010, 75, 245-248. [CrossRef] [PubMed]

69. Ross, A.J.; Dreiocker, F.; Schäfer, M.; Oomens, J.; Meijer, A.J.H.M.; Pickup, B.T.; Jackson, R.F.W. Evidence for the Role of Tetramethylethylenediamine in Aqueous Negishi Cross-Coupling: Synthesis of Nonproteinogenic Phenylalanine Derivatives on Water. J. Org. Chem. 2011, 76, 1727-1734. [CrossRef] [PubMed]

70. Bittner, S.; Scherzer, R.; Harlev, E. The five bromotryptophans. Amino Acids 2007, 33, 19-42. [CrossRef] [PubMed]

71. Konda-Yamada, Y.; Okada, C.; Yoshida, K.; Umeda, Y.; Arima, S.; Sato, N.; Kai, T.; Takayanagi, H.; Harigaya, Y. Convenient synthesis of $7^{\prime}$ - and $6^{\prime}$-bromo-D-tryptophan and their derivatives by enzymatic optical resolution using D-aminoacylase. Tetrahedron 2002, 58, 7851-7861. [CrossRef]

72. Kieffern, M.E.; Repka, L.M.; Reisman, S.E. Enantioselective Synthesis of Tryptophan Derivatives by a Tandem Friedel-Crafts Conjugate Addition/Asymmetric Protonation Reaction. J. Am. Chem. Soc. 2012, 134, 5131-5137. [CrossRef] [PubMed]

73. Blaser, G.; Sanderson, J.M.; Batsanov, A.S.; Howard, J.A.K. The facile synthesis of a series of tryptophan derivatives. Tetrahedron Lett. 2008, 49, 2795-2798. [CrossRef]

74. Winn, M.; Roy, A.D.; Grüschow, S.; Parameswaran, R.S.; Goss, R.J.M. A convenient one-step synthesis of L-aminotryptophans and improved synthesis of 5-fluorotryptophan. Bioorg. Med. Chem. Lett. 2008, 18, 4508-4510. [CrossRef] [PubMed]

75. Smith, D.R.M.; Willemse, T.; Gkotsi, D.S.; Schepens, W.; Maes, B.U.W.; Ballet, S.; Goss, R.J.M. The First One-Pot Synthesis of L-7-Iodotryptophan from 7-Iodoindole and Serine, and an Improved Synthesis of Other L-7-Halotryptophans. Org. Lett. 2014, 16, 2622-2625. [CrossRef] [PubMed]

76. Seibold, C.; Schnerr, H.; Rumpf, J.; Kunzendorf, A.; Hatscher, C.; Wage, T.; Ernyei, A.J.; Dong, C.; Naismith, J.H.; Van Pée, K.-H. A flavin-dependent tryptophan 6-halogenase and its use in modification of pyrrolnitrin biosynthesis. Biocatal. Biotransformation 2006, 24, 401-408. [CrossRef]

77. Zehner, S.; Kotzsch, A.; Bister, B.; Süssmuth, R.D.; Méndez, C.; Salas, J.A.; van Pée, K.-H. A Regioselective Tryptophan 5-Halogenase Is Involved in Pyrroindomycin Biosynthesis in Streptomyces rugosporus LL-42D005. Chem. Biol. 2005, 12, 445-452. [CrossRef] [PubMed]

78. Wang, L.; Brock, A.; Herberich, B.; Schultz, P.G. Expanding the Genetic Code of Escherichia coli. Science 2001, 292, 498-500. [CrossRef] [PubMed]

79. Xiao, H.; Schultz, P.W. At the Interface of Chemical and Biological Synthesis: An Expanded Genetic Code. Cold Spring Harb. Perspect. Biol. 2016, 8, 1-19. [CrossRef] [PubMed]

80. Liu, W.; Brock, A.; Chen, S.; Chen, S.; Schultz, P.G. Genetic incorporation of unnatural amino acids into proteins in mammalian cells. Nat. Meth. 2007, 4, 239-244. [CrossRef] [PubMed]

81. Liu, C.C.; Mack, A.V.; Brustad, E.M.; Mills, J.H.; Groff, D.; Smider, V.V.; Schultz, P.G. Evolution of Proteins with Genetically Encoded "Chemical Warheads". J. Am. Chem. Soc. 2009, 131, 9616-9617. [CrossRef] [PubMed]

82. Kodama, K.; Fukuzawa, S.; Nakayama, H.; Kigawa, T.; Sakamoto, K.; Yabuki, T.; Matsuda, N.; Shirouzu, M.; Takio, K.; Tachibana, K.; et al. Regioselective Carbon-Carbon Bond Formation in Proteins with Palladium Catalysis; New Protein Chemistry by Organometallic Chemistry. ChemBioChem 2006, 7, 134-139. [CrossRef] [PubMed] 
83. Brustad, E.; Bushey, M.L.; Lee, J.W.; Groff, D.; Liu, W.; Schultz, P.G. A Genetically Encoded Boronate-Containing Amino Acid. Angew. Chem. Int. Ed. 2008, 47, 8220-8223. [CrossRef] [PubMed]

84. Casalnuovo, A.L.; Calabrese, J.C. Palladium-Catalyzed Alkylations in Aqueous Media. J. Am. Chem. Soc. 1999, 112, 4324-4330. [CrossRef]

85. Tilley, J.W.; Sarabu, R.; Wagner, R.; Mulkerins, K. Preparation of Carboalkoxyalkylphenylalanine Derivatives from Tyrosine. J. Org. Chem. 1990, 55, 906-910. [CrossRef]

86. Shieh, W.-C.; Carlson, J.A. A Simple Asymmetric Synthesis of 4-Arylphenylalanines via Palladium-Catalyzed Cross-Coupling Reaction of Arylboronic Acids with Tyrosine Triflate. J. Org. Chem. 1992, 57, 379-381. [CrossRef]

87. Burk, M.J.; Lee, J.R.; Martinez, J.P. A Versatile Tandem Catalysis Procedure for the Preparation of Novel Amino Acids and Peptides J. Am. Chem. Soc. 1994, 116, 10847-10848. [CrossRef]

88. Kotha, S.; Lahiri, K. A New Approach for Modification of Phenylalanine Peptides by Suzuki-Miyaura Coupling Reaction. Bioorg. Med. Chem. Lett. 2001, 11, 2887-2890. [CrossRef]

89. Wang, W.; Xiong, C.; Zhang, J.; Hruby, V.J. Practical, assymmetric synthesis of aromatic-substituted bulky and hydrophobic tryptophan and phenylalanine derivatives. Tetrahedron 2002, 58, 3101-3110. [CrossRef]

90. Espuña, G.; Arsequell, G.; Valencia, G.; Barluenga, J.; Alvarez-Gutiérrez, J.M.; Ballesteros, A.; González, J.M. Regioselective Postsynthetic Modification of Phenylalanine Side Chains of Peptides Leading to Uncommon ortho-Iodinated Analogues. Angew. Chem. Int. Ed. 2004, 43, 325-329. [CrossRef] [PubMed]

91. Limbach, M.; Löweneck, M.; Schreiber, J.V.; Frackenpohl, J.; Seebach, D. Synthesis of $\beta^{3}$-HomophenylalanineDerived Amino Acids and Peptides by Suzuki Coupling in Solution and on Solid Support. Helv. Chim. Acta 2006, 89, 1427-1441. [CrossRef]

92. Knör, S.; Laufer, B.; Kessler, H. Efficient Enantioselective Synthesis of Condensed and Aromatic-RingSubstituted Tyrosine Derivatives. J. Org. Chem. 2006, 71, 5625-5630. [CrossRef] [PubMed]

93. Cerezo, V.; Afonso, A.; Planas, M.; Feliu, L. Synthesis of 5-arylhistidines via a Suzuki-Miyaura cross-coupling. Tetrahedron 2007, 63, 10445-10453. [CrossRef]

94. Prieto, M.; Mayor, S.; Rodríguez, K.; Lloyd-Williams, P.; Giralt, E. Racemization in Suzuki Couplings: A Quantitative Study Using 4-Hydroxyphenylglycine and Tyrosine Derivatives as Probe Molecules. J. Org. Chem. 2007, 72, 1047-1050. [CrossRef] [PubMed]

95. Dumas, A.; Peramo, A.; Desmaële, D.; Couvreur, P. PLGA-PEG-supported Pd Nanoparticles as Efficient Catalysts for Suzuki-Miyaura Coupling Reactions in Water. Chimia 2016, 70, 252-257. [CrossRef] [PubMed]

96. Deb Roy, A.; Grüshow, S.; Cairns, N.; Goss, R.J.M. Gene Expression Enabling Synthetic Diversification of Natural Products: Chemogenetic Generation of Pacidamycin Analogs. J. Am. Chem. Soc. 2010, 132, 12243-12245. [PubMed]

97. Willemse, T.; Van Imp, K.; Vlijmen, H.W.T.; Schepens, W.; Goss, R.J.M.; Maes, B.U.W.; Ballet, S. Suzuki-Miyaura Diversification of Amino Acids and Dipeptides in Aqueous Media. ChemCatChem 2015, 7, 2055-2070. [CrossRef]

98. Frese, M.; Schnepel, C.; Minges, H.; Voß, H.; Feiner, R.; Sewald, N. Modular Combination of Enzymatic Halogenation of Tryptophan with Suzuki-Miyaura Cross-Coupling Reactions. ChemCatChem 2016, 8, 1799-1803. [CrossRef]

99. Maity, J.; Honcharenko, D.; Strömberg, R. Synthesis of fluorescent D-amino acids with 4-acetamidobiphenyl and 4- $N, N$-dimethylamino-1,8-naphthalimido containing side chains. Tetrahedron Lett. 2015, 56, 4780-4783. [CrossRef]

100. Qiao, J.X.; Fraunhoffer, K.J.; Hsiao, Y.; Li, Y.-X.; Wang, C.; Wang, T.C.; Poss, M.A. Synthesis of Fmoc-Protected Arylphenylalanines (Bip Derivatives) via Nonaqueous Suzuki-Miyaura Cross-Coupling Reactions. J. Org. Chem. 2016, 81, 9499-9506. [CrossRef] [PubMed]

101. Jana, R.; Pathak, T.P.; Sigman, M.S. Advances in Transition Metal (Pd,Ni,Fe)-Catalyzed Cross-Coupling Reactions Using Alkyl-organometallics as Reaction Partners. Chem. Rev. 2011, 111, 1417-1492. [CrossRef] [PubMed]

102. Yang, W.; Gao, X.; Wang, B. Boronic Acid Compounds as Potential Pharmaceutical Agents. Med. Res. Rev. 2003, 23, 346-368. [CrossRef] [PubMed]

103. Satoh, Y.; Gude, C.; Chan, K.; Firooznia, F. Synthesis of 4-Substitured Phenylalanine Derivatives by Cross-Coupling Reaction of $p$-Boronophenylalanine. Tetrahedron. Lett. 1997, 38, 7645-7648. [CrossRef] 
104. Firooznia, F.; Gude, C.; Chan, K.; Marcopulos, N.; Satoh, Y. Enantioselective Synthesis of 4-Substituted Phenylalanines by Cross-Coupling Reactions. Tetrahedron. Lett. 1999, 40, 213-216. [CrossRef]

105. Iimura, S.; Wu, W. Palladium-catalyzed borylation of L-tyrosine triflate derivative with pinacolborane: practical route to 4-borono-L-phenylalanine (L-BPA) derivatives. Tetrahedron Lett. 2010, 51, 1353-1355. [CrossRef]

106. Jung, M.E.; Lazarova, T.I. New Efficient Method for the Total Synthesis of (S,S)-Isodityrosine from Natural Amino Acids. J. Org. Chem. 1999, 64, 2976-2977. [CrossRef] [PubMed]

107. Malan, C.; Morin, C. A Concise Preparation of 4-Borono-L-phenylalanine (L-BPA) from L-Phenylalanine. J. Org. Chem. 1998, 63, 8019-8020. [CrossRef]

108. Lépine, R.; Zhu, J. Microwave-Assisted Intramolecular Suzuki-Miyaura Reaction to Macrocycle, a Concise Asymmetric Total Synthesis of Biphenomycin B. Org. Lett. 2005, 7, 2981-2984. [CrossRef] [PubMed]

109. Wienhold, F.; Claes, D.; Graczyk, K.; Maison, W. Synthesis of Functionalized Benzoboroxoles for the Construction of Boronolectins. Synthesis 2011, 24, 4059-4067.

110. Kallepalli, V.A.; Shi, F.; Paul, S.; Onyeozili, E.N.; Maleczka, R.E.; Smith, M.R. Boc Groups as Protectors and Directors for Ir-Catalyzed C-H Borylation of Heterocycles. J. Org. Chem. 2009, 74, 9199-9201. [CrossRef] [PubMed]

111. Meyer, F.-M.; Liras, S.; Guzman-Perez, A.; Perrault, C.; Bian, J.; James, K. Functionalization of Aromatic Amino Acids via Direct C-H Activation: Generation of Versatile Building Blocks for Accessing Novel Peptide Space. Org. Lett. 2010, 12, 3870-3873. [CrossRef] [PubMed]

112. Audi, H.; Rémond, E.; Eymin, M.-J.; Tessier, A.; Malacea-Kabbara, R.; Jugé, S. Modular Hemisyntheses of Boronato- and Trifluoroborato-Substituted L-NHBoc Amino Acid and Peptide Derivatives. Eur. J. Org. Chem. 2013, 2013, 7960-7972. [CrossRef]

113. Bartolucci, S.; Bartoccini, F.; Righi, M.; Piersanti, G. Direct, Regioselective, and Chemoselective Preparation of Novel Boronated Tryptophans by Friedel-Crafts Alkylation. Org. Lett. 2011, 14, 600-603. [CrossRef] [PubMed]

114. Colgin, N.; Flinn, T.; Cobb, S.L. Synthesis and properties of MIDA boronate containing aromatic amino acids: New peptide building blocks. Org. Biomol. Chem. 2011, 9, 1864-1870. [CrossRef] [PubMed]

115. Gong, Y.; He, W. Direct Synthesis of Unprotected 4-Aryl Phenylalanines via the Suzuki Reaction under Microwave Irradiation. Org. Lett. 2002, 4, 3803-3805. [CrossRef] [PubMed]

116. Čapek, P.; Hocek, M. Efficient One-Step Synthesis of Optically Pure (Adenin-8-yl)phenylalanine Nucleosides. Synlett 2005, 19, 3005-3007.

117. Čapek, P.; Pohl, R.; Hocek, M. Cross-Coupling reactions of unprotected halopurine bases, nucleosides, nucleotides and nucleoside triphosphates with 4-boronophenylalanine in water. Synthesis of (purin-8-yl)and (purin-6-yl)phenylalanines. Org. Biomol. Chem. 2006, 4, 2278-2284. [CrossRef] [PubMed]

118. Bartocinni, S.; Bartolucci, M.M.; Piersanti, G. A simple, modular synthesis of C4-substituted tryptophan derivatives. Org. Biomol. Chem. 2016, 14, 10095-10100. [CrossRef] [PubMed]

119. Loach, R.P.; Fenton, O.S.; Amaike, K.; Siegel, D.S.; Ozkal, E.; Movassaghi, M. C7-Derivatization of C3-Alkylindoles Including Tryptophans and Tryptamines. J. Org. Chem. 2014, 79, 11254-11263. [CrossRef] [PubMed]

120. Afonso, A.; Feliu, L.; Planas, M. Solid-Phase synthesis of biaryl cyclic peptides by borylation and microwave assisted intramolecular Suzuki-Miyaura reaction. Tetrahedron 2011, 67, 2238-2245. [CrossRef]

121. Campbell, A.D.; Raynham, T.M.; Taylor, R.J.K. The Synthesis of Novel Amino Acids v/a Hydroboration-Suzuki Cross Coupling. Tetrahedron Lett. 1999, 40, 5263-5266. [CrossRef]

122. Sabat, M.; Johnson, C.R. Synthesis of Unnatural Amino Acids via Suzuki Cross-Coupling of Enantiopure Vinyloxazolidine Derivatives. Org. Lett. 2000, 2, 1089-1092. [CrossRef] [PubMed]

123. Collier, P.N.; Campbell, A.D.; Patel, I.; Taylor, R.J.K. The direct synthesis of novel enantiomerically pure $\alpha$-amino acids in protected form via Suzuki cross-coupling. Tetrahedron Lett. 2000, 41, 7115-7119. [CrossRef]

124. Rodríguez, A.; Miller, D.D.; Jackson, R.F.W. Combined application of organozinc chemistry and one-pot hydroboration-Suzuki coupling to the synthesis of amino acids. Org. Biomol. Chem. 2003, 1, 973-977. [CrossRef] [PubMed]

125. Reddy, V.J.; Chandra, J.S.; Reddy, M.V.R. Concise synthesis of $\omega$-borono- $\alpha$-amino acids. Org. Biomol. Chem. 2007, 5, 889-891. [CrossRef] [PubMed] 
126. Harvey, J.E.; Kenworthy, M.N.; Taylor, R.J.K. Synthesis of non-proteinogenic phenylalanine analogues by Suzuki cross-coupling of a serine-derived alkyl boronic acid. Tetrahedron Lett. 2004, 45, 2467-2471. [CrossRef]

127. Zhang, Z.Q.; Yang, C.T.; Liang, L.J.; Xiao, B.; Lu, X.; Liu, J.-H.; Sun, Y.-Y.; Marder, T.B.; Fu, Y. Copper-Catalyzed/Promoted Cross-coupling of gem-Diborylalkanes with Nonactivated Primary Alkyl Halides: An Alternative Route to Alkylboronic Esters. Org. Lett. 2014, 16, 6342-6345. [CrossRef] [PubMed]

128. He, J.; Jiang, H.; Takise, R.; Zhu, R.-Y.; Chen, G.; Dai, H.-X.; Murali Dhar, T.G.; Shi, J.; Zhang, H.; Cheng, P.T.W.; et al. Ligand-Promoted Borylation of C(sp3)-H Bonds with Palladium(II) Catalysts. Angew. Chem. Int. Ed. 2016, 55, 785-789. [CrossRef] [PubMed]

129. Yoburn, J.C.; Van Vranken, D.L. Synthesis of Dityrosine Cross-Linked Peptide Dimers Using the Miyaura-Suzuki Reaction. Org. Lett. 2003, 5, 2817-2820. [CrossRef] [PubMed]

130. Hutton, C.A.; Skaff, O. A convenient preparation of dityrosine via Miyaura borylation-Suzuki coupling of iodotyrosine derivatives. Tetrahedron Lett. 2003, 44, 4895-4898. [CrossRef]

131. Kotha, S.; Shah, V.R.; Halder, S.; Vinodkumar, R.; Lahiri, K. Synthesis of bis-armed amino acid derivatives via the alkylation of ethyl isocyanoacetate and the Suzuki-Miyaura cross-coupling reaction. Amino Acids 2007, 32, 387-394. [CrossRef] [PubMed]

132. Prieto, M.; Mayor, S.; Lloyd-Williams, P.; Giralt, E. Use of the SPhos Ligand to Suppress Racemization in Arylpinacolboronate Ester Suzuki Couplings Involving r-Amino Acids. Synthesis of Biaryl Derivatives of 4-Hydroxyphenylglycine, Tyrosine, and Tryptophan. J. Org. Chem. 2009, 74, 9202-9205. [CrossRef] [PubMed]

133. Cho, J.H.; Prickett, C.D.; Shaughnessy, K.H. Efficient Sonogashira Coupling of Unprotected Halonucleosides in Aqueous Solvents Using Water-Soluble Palladium Catalysts. Eur. J. Org. Chem. 2010, 2010, 3678-3683. [CrossRef]

134. Roy, S.; Plenio, H. Sulfonated N-Heterocyclic Carbenes for Pd-Catalyzed Sonogashira and Suzuki-Miyaura Coupling in Aqueous Solvents. Adv. Synth. Catal. 2010, 352, 1014-1022. [CrossRef]

135. Ma, X.; Wang, H.; Chen, W. N-Heterocyclic Carbene-Stabilized Palladium Complexes as Organometallic Catalysts for Bioorthogonal Cross-Coupling Reactions. J. Org. Chem. 2014, 79, 8652-8658. [CrossRef] [PubMed]

136. Fleckenstein, C.; Roy, S.; Leuthäußer, S.; Plenio, H. Sulfonated N-heterocyclic carbenes for Suzuki coupling in water. Chem. Commun. 2007, 27, 2870-2872. [CrossRef] [PubMed]

137. Godoy, F.; Segarra, C.; Poyatos, M.; Peris, E. Palladium Catalysts with Sulfonate-Functionalized-NHC Ligands for Suzuki-Miyaura Cross-Coupling Reactions in Water. Organometallics 2011, 30, 684-688. [CrossRef]

138. Chatterjee, A.; Ward, T.R. Recent Advances in the Palladium Catalyzed Suzuki-Miyaura Cross-Coupling Reaction in Water. Catal. Lett. 2016, 146, 820-840. [CrossRef]

139. Lipshutz, B.H.; Ghorai, S. "Designer"-Surfactant-Enabled Cross-Couplings in Water at Room Temperature. Aldrichim. Acta 2012, 45, 3-16.

140. Li, J.-H.; Zhang, X.-D.; Xie, Y.-X. Efficient $\mathrm{Pd}(\mathrm{OAc})_{2} /$ pyrimidine catalytic system for Suzuki-Miyaura Cross-Coupling reaction. Synlett 2005, 12, 1897-1900. [CrossRef]

141. Li, S.; Lin, Y.; Cao, J.; Zhang, S. Guanidine/Pd(OAc) ${ }_{2}$-Catalyzed Room Temperature Suzuki Cross-Coupling Reaction in Aqueous Media under Aerobic Conditions. J. Org. Chem. 2007, 72, 4067-4072. [CrossRef] [PubMed]

142. Gao, Z.; Gouverneur, V.; Davis, B.G. Enhanced Aqueous Suzuki-Miyaura Coupling Allows Site-Specific Polypeptide ${ }^{18}$ F-Labeling. J. Am. Chem. Soc. 2013, 135, 13612-13615. [CrossRef] [PubMed]

143. Vilaró, M.; Arsequell, G.; Valencia, G.; Ballesteros, A.; Barluenga, J. Arylation of Phe and Tyr Side Chains of Unprotected Peptides by a Suzuki-Miyaura Reaction in Water. Org. Lett. 2008, 10, 3243-3245. [CrossRef] [PubMed]

144. Lin, Y.A.; Chalker, J.M.; Davis, B.G. Olefin Metathesis for Site-Selective Protein Modification. ChemBioChem 2009, 10, 959-969. [CrossRef] [PubMed]

145. Ai, H.-W.; Shen, W.; Brustad, E.; Schultz, P.G. Genetically Encoded Alkenes in Yeast. Angew. Chem. Int. Ed. 2010, 49, 935-937. [CrossRef] [PubMed]

146. Ojida, A.; Tsutsumi, H.; Kasagi, N.; Hamachi, I. Suzuki coupling for protein modification. Tetrahedron Lett. 2005, 46, 3301-3305. [CrossRef]

147. Lorsbach, B.A.; Kurth, M.J. Carbon-Carbon Bond Forming Solid-Phase Reactions. Chem. Rev. 1999, 99, 1549-1581. [CrossRef] [PubMed] 
148. Colombel, V.; Presset, M.; Oehlrich, D.; Rombouts, F.; Molander, G.A. Synthesis and Reactivity of SolidSupported Organotrifluoroborates in Suzuki Cross-Coupling. Org. Lett. 2012, 14, 1680-1683. [CrossRef] [PubMed]

149. Yokum, T.S.; Barany, G. Strategy in Solid-Phase Peptide Syntesis. In Solid-Phase Synthesis: A Practical Guide; Kates, S.A., Albericio, F., Eds.; Marcel Dekker, Inc.: New York, NY, USA, 2000; Volume 1, pp. 79-103.

150. Adams, J.H.; Cook, R.M.; Hudson, D.; Jammalamadaka, V.; Lyttle, M.H.; Songster, M.F. A Reinvestigation of the Preparation, Properties, and Applications of Aminomethyl and 4-Methylbenzhydrylamine Polystyrene Resins. J. Org. Chem. 1998, 63, 3706-3716. [CrossRef]

151. García-Martín, F.; Quintanar-Audelo, M.; García-Ramos, Y.; Cruz, L.J.; Gravel, C.; Furic, R.; Côté, S.; Tulla-Puche, J.; Albericio, F. ChemMatrix, a Poly(ethylene glycol)-Based Support for the Solid-Phase Synthesis of Complex Peptides. J. Comb. Chem. 2006, 8, 213-220. [CrossRef] [PubMed]

152. Colombo, A.; Fernàndez, J.-C.; de la Figuera, N.; Fernàndez-Forner, D.; Forns, P.; Albericio, F. Solid-Phase Preparation of a Library Based on a Phenylalanine Scaffold. QSAR Comb. Sci. 2005, 24, 913-922. [CrossRef]

153. Nielsen, T.E.; Le Quement, S.; Meldal, M. Solid-Phase synthesis of biarylalanines via Suzuki cross-coupling and intramolecular $N$-acyliminium Pictet-Spengler reactions. Tetrahedron Lett. 2005, 46, 7959-7962. [CrossRef]

154. Le Quement, S.; Nielsen, T.E.; Meldal, M. Solid-Phase Synthesis of Aryl-Substituted Thienoindolizines: Sequential Pictet-Spengler, Bromination and Suzuki Cross-Coupling Reactions of Thiophenes. J. Comb. Chem. 2008, 10, 447-455. [CrossRef] [PubMed]

155. Le Quement, S.; Ishoey, M.; Petersen, M.T.; Thastrup, J.; Hagel, G.; Nielsen, T.E. Solid-Phase Synthesis of Smac Peptidomimetics Incorporating Triazoloprolines and Biarylalanines. ACS Comb. Sci. 2011, 13, 667-675. [CrossRef] [PubMed]

156. Haug, D.E.; Stensen, W.; Svendsen, J.S. Application of the Suzuki-Miyaura cross-coupling to increase antimicrobial potency generates promising novel antibacterials. Bioorg. Med. Chem. Lett. 2007, 17, 2361-2364. [CrossRef] [PubMed]

157. Doan, N.-D.; Bourgault, S.; Létourneau, M.; Fournier, A. Effectiveness of the Suzuki-Miyaura Cross-Coupling Reaction for Solid-Phase Peptide Modification. J. Comb. Chem. 2008, 10, 44-51. [CrossRef] [PubMed]

158. Afonso, A.; Rosés, C.; Planas, M.; Feliu, L. Biaryl Peptides from 4-Iodophenylalanine by Solid-Phase Borylation and Suzuki-Miyaura Cross-Coupling. Eur. J. Org. Chem. 2010, 2010, 1461-1468. [CrossRef]

159. Cerezo, V.; Amblard, M.; Martinez, J.; Verdié, P.; Planas, M.; Feliu, L. Solid-phase synthesis of 5-arylhistidines via a microwave-assisted Suzuki-Miyaura cross-coupling. Tetrahedron 2008, 64, 10538-10545. [CrossRef]

160. Elder, A.M.; Rich, D.H. Two Syntheses of the 16- and 17-Membered DEF Ring Systems of Chloropeptin and Complestatin. Org. Lett. 1999, 1, 1443-1446. [CrossRef] [PubMed]

161. Carbonelle, A.-C.; Zhu, J. A Novel Synthesis of Biaryl-Containing Macrocycles by a Domino Miyaura Arylboronate Formation: Intramolecular Suzuki Reaction. Org. Lett. 2000, 2, 3477-3480. [CrossRef]

162. Boisnard, S.; Carbonelle, A.-C.; Zhu, J. Studies on the Total Synthesis of RP 66453: Synthesis of Fully Functionalized 15-Membered Biaryl-Containing Macrocycle. Org. Lett. 2001, 3, 2061-2064. [CrossRef] [PubMed]

163. Waldmann, H.; He, Y.-P.; Tan, H.; Arve, L.; Arndt, H.-D. Flexible total synthesis of biphenomycin B. Chem. Commun. 2008, 43, 5562-5564. [CrossRef] [PubMed]

164. Lin, S.; Danishefsky, S.J. The Total Synthesis of Proteasome Inhibitors TMC-95A and TMC-95B: Discovery of a New Method to Generate cis-Propenyl Amides. Angew. Chem. Int. Ed. 2002, 41, 512-515. [CrossRef]

165. Berthelot, A.; Piguel, S.; Le Dour, G.; Vidal, J. Synthesis of Macrocyclic Peptide Analogues of Proteasome Inhibitor TMC-95A. J. Org. Chem. 2003, 68, 9835-9838. [CrossRef] [PubMed]

166. Inoue, M.; Sakazaki, H.; Furyama, H.; Hirama, M. Total Synthesis of TMC-95A. Angew. Chem. Int. Ed. 2003, 42, 2654-2657. [CrossRef] [PubMed]

167. Kaiser, M.; Siciliano, C.; Assfalg-Machleidt, I.; Groll, M.; Milbradt, A.; Moroder, L. Synthesis of a TMC-95A Ketomethylene Analogue by Cyclization via Intramolecular Suzuki Coupling. Org. Lett. 2003, 5, 3435-3437. [CrossRef] [PubMed]

168. Coste, A.; Bayle, A.; Marrot, J.; Evano, G. A Convergent Synthesis of the Fully Elaborated Macrocyclic Core of TMC-95A. Org. Lett. 2014, 16, 1306-1309. [CrossRef] [PubMed]

169. Dufour, J.; Neuville, L.; Zhu, J. Intramolecular Suzuki-Miyaura Reaction for the Total Synthesis of Signal Peptidase Inhibitors, Arylomycins A2 and B2. Chem. Eur. J. 2010, 16, 10523-10534. [CrossRef] [PubMed] 
170. Jia, X.; Bois-Choussy, M.; Zhu, J. Synthesis of Diastereomers of Complestatin and Chloropeptin I: Substrate-Dependent Atropstereoselectivity of the Intramolecular Suzuki-Miyaura Reaction. Angew. Chem. Int. Ed. 2008, 47, 4167-4172. [CrossRef] [PubMed]

171. Wang, Z.; Bois-Choussy, M.; Jia, Y.; Zhu, J. Total Synthesis of Complestatin (Chloropeptin II). Angew. Chem. Int. Ed. 2010, 49, 2018-2022. [CrossRef] [PubMed]

172. Moschitto, M.J.; Lewis, C.A. Synthesis of the Rubiyunnanin B Core Aglycon. Eur. J. Org. Chem. 2016, 2016, 4773-4777. [CrossRef]

173. Afonso, A.; Cussó, O.; Feliu, L.; Planas, M. Solid-Phase Synthesis of Biaryl Cyclic Peptides Containing a 3-Aryltyrosine. Eur. J. Org. Chem. 2012, 2012, 6204-6211. [CrossRef]

174. Meyer, F.-M.; Collins, J.C.; Borin, B.; Bradow, J.; Liras, S.; Limberakis, C.; Mathiowetz, A.M.; Philippe, L.; Price, D.; Song, K.; et al. Biaryl-Bridged Macrocyclic Peptides: Conformational Constraint via Carbogenic Fusion of Natural Amino Acid Side Chains. J. Org. Chem. 2012, 77, 3099-3114. [CrossRef] [PubMed]

175. Antos, J.M.; Francis, M.B. Transition metal catalyzed methods for site-selective protein modification. Curr. Opin. Chem. Biol. 2006, 10, 253-262. [CrossRef] [PubMed]

176. Chankeshwara, S.V.; Indrigo, E.; Bradley, M. Palladium-mediated chemistry in living cells. Curr. Opin. Chem. Biol. 2014, 21, 128-135. [CrossRef] [PubMed]

177. Sasmal, P.K.; Streu, C.N.; Meggers, E. Metal Complex Catalysis in Living Biological Systems. Chem. Commun. 2013, 49, 1581-1587. [CrossRef] [PubMed]

178. Takaoka, Y.; Ojida, A.; Hamachi, I. Protein Organic Chemistry and Applications for Labeling and Engineering in Live-Cell Systems. Angew. Chem. Int. Ed. 2013, 52, 4088-4106. [CrossRef] [PubMed]

179. Garrett, C.E.; Prasad, K. The Art of Meeting Palladium Specifications in Active Pharmaceutical Ingredients Produced by Pd-Catalyzed Reactions. Adv. Synth. Catal. 2004, 346, 889-900. [CrossRef]

180. Spicer, C.D.; Davis, B.G. Palladium-Mediated site-selective Suzuki-Miyaura protein modification at genetically encoded aryl halides. Chem. Commun. 2011, 47, 1698-1700. [CrossRef] [PubMed]

181. Magano, J.; Dunetz, J.R. Large-Scale Applications of Transition Metal-Catalyzed Couplings for the Synthesis of Pharmaceuticals. Chem. Rev. 2011, 111, 2177-2250. [CrossRef] [PubMed]

182. Molnár, Á. Efficient, Selective, and Recyclable Palladium Catalysts in Carbon-Carbon Coupling Reactions. Chem. Rev. 2011, 111, 2251-2320. [CrossRef] [PubMed]

183. Lamblin, M.; Nasser-Hardy, L.; Hierso, J.-C.; Fouquet, E.; Felpin, F.-X. Recyclable Heterogeneous Palladium Catalysts in Pure Water: Sustainable Developments in Suzuki, Heck, Sonogashira and Tsuji-Trost Reactions. Adv. Synth. Catal. 2010, 352, 33-79. [CrossRef]

184. Zhang, Q.; Su, H.; Luo, J.; Wei, Y. Recyclable palladium(II) imino-pyridine complex immobilized on mesoporous silica as a highly active and recoverable catalyst for Suzuki-Miyaura coupling reactions in aqueous medium. Tetrahedron 2013, 69, 447-454. [CrossRef]

185. Shokouhimehr, M.; Lee, J.E.; Han, S.I.; Hyeon, T. Magnetically recyclable hollow nanocomposite catalysts for heterogeneous reduction of nitroarenes and Suzuki reactions. Chem. Commun. 2013, 49, 4779-4781. [CrossRef] [PubMed]

186. Shokouhimehr, M.; Kim, T.; Jun, S.W.; Shin, K.; Jang, Y.; Kim, B.H.; Kim, J.; Hyeon, T. Magnetically separable carbon nanocomposite catalysts for efficient nitroarene reduction and Suzuki reactions. Appl. Catal. A 2014, 476, 133-139. [CrossRef]

187. Choi, K.-H.; Shokouhimehr, M.; Sung, Y.-E. Heterogeneous Suzuki Cross-Coupling Reaction Catalyzed by Magnetically Recyclable Nanocatalyst. Bull. Korean Chem. Soc. 2013, 34, 1477-1480. [CrossRef]

188. Karimi, B.; Akhavan, P.F. Main-Chain NHC-palladium polymer as a recyclable self-supported catalyst in the Suzuki-Miyaura coupling of aryl chlorides in water. Chem. Commun. 2009, 25, 3750-3752. [CrossRef] [PubMed]

189. Lombardo, M.; Chiarucci, M.; Trombini, C. A recyclable triethylammonium ion-tagged diphenylphosphine palladium complex for the Suzuki-Miyaura reaction in ionic liquids. Green Chem. 2009, 11, 574-579. [CrossRef]

190. Edwards, G.A.; Trafford, M.A.; Hamilton, A.E.; Buxton, A.M.; Bardeaux, M.C.; Chalker, J.M. Melamine and Melamine-Formaldehyde Polymers as Ligands for Palladium and Application to Suzuki-Miyaura Cross-Coupling Reactions in Sustainable Solvents. J. Org. Chem. 2014, 79, 2094-2104. [CrossRef] [PubMed]

191. Spicer, C.D.; Triemer, T.; Davis, B.G. Palladium-Mediated Cell-Surface Labeling. J. Am. Chem.Soc. 2012, 134, 800-803. [CrossRef] [PubMed] 
192. Alconcel, S.N.S.; Baas, A.S.; Maynard, H.D. FDA-Approved poly(ethylene glycol)-protein conjugate drugs. Polym. Chem. 2011, 2, 1442-1448. [CrossRef]

193. Craik, D.J.; Fairlie, D.P.; Liras, S.; Price, D. The future of peptide-based drugs. Chem. Biol. Drug. Des. 2013, 81, 136-147. [CrossRef] [PubMed]

194. Hagmann, W.K.; Durette, P.L.; Lanza, T.; Kevin, N.J.; de Laszlo, S.E.; Kopka, I.E.; Young, D.; Magriotis, P.A.; Li, B.; Lin, L.S.; et al. The Discovery of Sulfonylated Dipeptides as Potent VLA-4 Antagonists. Bioorg. Med. Chem. Lett. 2001, 11, 2709-2713. [CrossRef]

195. Yang, G.X.; Chang, L.L.; Truong, Q.; Doherty, G.A.; Magriotis, P.A.; de Laszlo, S.E.; Li, B.; MacCoss, M.; Kidambi, U.; Egger, L.A.; et al. N-Tetrahydrofuroyl-(L)-phenylalanine derivatives as potent VLA-4 antagonists. Bioorg. Med. Chem. Lett. 2002, 12, 1497-1500. [CrossRef]

196. Sircar, I.; Gudmundsson, K.S.; Martin, R.; Liang, J.; Nomura, S.; Jayakumar, H.; Teegarden, B.R.; Nowlin, D.M.; Cardarelli, P.M.; Mah, J.R.; et al. Synthesis and SAR of N-Benzoyl-L-Biphenylalanine Derivatives: Discovery of TR-14035, A Dual $\alpha 4 \beta 1 / \alpha 4 \beta 7$ Integrin Antagonisty. Bioorg. Med. Chem. 2002, 10, 2051-2066. [CrossRef]

197. Castanedo, G.M.; Sailes, F.C.; Dubree, N.J.P.; Nicholas, J.B.; Caris, L.; Clark, K.; Keating, S.M.; Beresini, M.H.; Chiu, H.; Fong, S.; et al. Solid-Phase Synthesis of Dual $\alpha 4 \beta 1 / \alpha 4 \beta 7$ Integrin Antagonists: Two Scaffolds with Overlapping Pharmacophores. Bioorg. Med. Chem. Lett. 2002, 12, 2913-2917. [CrossRef]

198. Mapelli, C.; Natarajan, S.I.; Meyer, J.-P.; Bastos, M.M.; Bernatowicz, M.S.; Lee, V.G.; Pluscec, J.; Riexinger, D.J.; Sieber-McMaster, E.S.; Constantine, K.L.; et al. Eleven Amino Acid Glucagon-like Peptide-1 Receptor Agonists with Antidiabetic Activity. J. Med. Chem. 2009, 52, 7788-7799. [CrossRef] [PubMed]

199. Hoang, H.N.; Song, K.; Hill, T.A.; Derksen, D.R.; Edmonds, D.J.; Kok, W.M.; Limberakis, C.; Liras, S.; Loria, P.M.; Mascitti, V.; et al. Short Hydrophobic Peptides with Cyclic Constraints Are Potent Glucagon-like Peptide-1 Receptor (GLP-1R) Agonists. J. Med. Chem. 2015, 58, 4080-4085. [CrossRef] [PubMed]

200. Haug, B.E.; Skar, M.L.; Svendsen, J.S. Bulky Aromatic Amino Acids Increase the Antibacterial Activity of 15-Residue Bovine Lactoferricin Derivatives. J. Peptide Sci. 2001, 7, 425-432. [CrossRef] [PubMed]

201. Lau, Q.Y.; Ng, F.M.; Cheong, J.W.D.; Yap, Y.Y.A.; Tan, Y.Y.F.; Jureen, R.; Hill, J.; Chia, C.S.B. Discovery of an ultra-short linear antibacterial tetrapeptide with anti-MRSA activity from a structure-activity relationship study. Eur. J. Med. Chem. 2015, 105, 138-144. [CrossRef] [PubMed]

202. Ng-Choi, I.; Soler, M.; Cerezo, V.; Badosa, E.; Montesinos, E.; Planas, M.; Feliu, L. Solid-Phase Synthesis of 5-Arylhistidine-Containing Peptides with Antimicrobial Activity Through a Microwave-Assisted Suzuki-Miyaura Cross-Coupling. Eur. J. Org. Chem. 2012, 2012, 4321-4332. [CrossRef]

203. Wuts, P.G.M.; Simons, L.J.; Metzger, B.P.; Sterling, R.C.; Slightom, J.L.; Elhammer, A.P. Generation of Broad-Spectrum Antifungal Drug Candidates from the Natural Product Compound Aureobasidin A. ACS Med. Chem. Lett. 2015, 6, 645-649. [CrossRef] [PubMed]

(c) 2017 by the authors. Licensee MDPI, Basel, Switzerland. This article is an open access article distributed under the terms and conditions of the Creative Commons Attribution (CC BY) license (http://creativecommons.org/licenses/by/4.0/). 